\title{
Framing for Success: Governance of Swedish School Mathematics, 1980-1995
}

\author{
Johan Prytz
}

\begin{abstract}
This article examines the design of the mathematics curriculum applied in Sweden between 1980 and 1995 and how this design affected student results between two international tests, SIMS1980 and TIMSS1995. During this period, the results in mathematics improved on a general level, but in some topics it did not. The results increased significantly in arithmetic, but very little in algebra. I investigate in what respect the arithmetic and algebra curricula were designed differently. The analysed materials are syllabus, commentary material, tests, and textbooks. The analysis is based on Bernstein's theory on classification and framing. The main conclusion is that strong framing in the curriculum can be associated with better student results in TIMSS and evidence for a causal relation between these entities is presented. On the basis of my finding, I raise a critical question about the change in governing policy that took place in Sweden between 1975 and 2000.
\end{abstract}

Keywords $\bullet$ mathematics education, governance, curriculum, textbooks, student results

\section{Introduction}

Between 1975 and 2000, there was a shift in the policy of governing Swedish schools. The school system was considered too centralised and various parts of the system were reformed in accordance with an agenda of decentralisation. This shift in governance policy also involved the teaching. A central object in this respect was the national school subject curricula; their design was supposed to become less regulating. However, few studies have examined how this shift in governing policy and curriculum design did impact teaching, learning, and student results. ${ }^{1}$

This study fills the gap in knowledge about how curriculum design as applied in Sweden between 1980 and 1995 affected student results. Swedish school mathematics (years 1-9) is a relevant case for that end. During this period, the results in international tests improved greatly; however, much of this improvement was related to better results in arithmetic; the improvements in algebra, geometry, and statistics were much smaller. Therefore, if the arithmetic and algebra curriculum designs were not the same, this difference could explain the differences in re sults. Importantly, only one national curriculum was in effect between 1980 and 1995, which is the curriculum of 1980 . The first aim of this article is to describe the design of the arithmetic and algebra curricula. The second aim is to examine whether differences

1 The terms "curriculum" and syllabus occurs on several places in the article. Curriculum refers to a wider set of documents issued by the state that regulated the teaching. The curriculum includes the syllabi for each school subject, the commentary materials to the syllabi, diagnose material and national tests.

Johan Prytz is Associate Professor of Education at the Department of Education Uppsala University, Sweden. Email: johan.prytz@edu.uu.se. 
in curriculum design can explain why the Second International Mathematics Study in 1980 (SIMS) and the Third International Mathematics and Science Study in 1995 (TIMSS) produced different results. To better understand the relation between curriculum design and student results, the study also examines textbooks. The analysis of curriculum and textbooks is based on Bernstein's (1974) theory of classification and framing.

The first section of this article reviews previous research. The next section, Theory and method, follows Bernstein's (1974) theory of classification and framing; and research questions are introduced. The Background section examines the mathematics curriculum that preceded the 1980 curriculum and the results of Swedish students in various tests between 1970 and 1995. And then the analysis and the answers to the questions are presented in the following sections. The heading of the sections are Classification in syllabus and commentary material, Framing in syllabus and commentary material, Classification and framing in the national tests, and Classification and framing in the textbooks. The final section, Conclusions, synthesises the preceding analytical sections.

\section{Previous research}

Several university textbooks as well as research articles on curriculum theory or history of education have described the decentralisation of the Swedish school governance between 1975 and 2000, which was preceded by a long period of centralisation. ${ }^{2}$ The goal of decentralisation was to move decision making from national institutions (i.e., parliament and the central school authorities) to local institutions (i.e., school boards and even schools). This process concerned all three types of school governance: judicial governance (laws and regulations); economic governance (allocation of resources); and ideological governance (specification of goals, contents, and performance). Nevertheless, this was not a complete novelty. As early as the 1930 s and 40s, governmental investigations expressed ambitions for decentralisation and indeed municipalities had received more influence in some areas by the early 1960 s. $^{3}$ In the late 1970 s and in the1980s, however, several governmental investigations questioned the prevailing model of governance. Centralisation and too detailed regulations was considered a problem as these investigations emphasised the lack of influence municipalities, students, and parents had over local schools. To counter this perceived insufficiency, judicial, economic, and ideological governance

2 Examples of university textbooks: Pia Skott, Utbildningspolitik och läroplanshistoria, in Utbildningshistoria: En introduktion, ed. Esbjörn Larsson and Johannes Westberg (Lund: Studentlitteratur, 2011), 330-36; Bo Lindensjö and Ulf P. Lundgren, Utbildningsreformer och politisk styrning (Stockholm: Liber, 2014), 81-83, 93-97; Gunnar Richardson, Svensk utbildningshistoria: Skola och samhälle förr och nu, 8. rev. ed. (Lund: Studentlitteratur, 2010), 95, 159. Examples of research treatises: Mattias Börjesson, Från likvärdighet till marknad: En studie av offentligt och privat inflytande över skolans styrning i svensk utbildningspolitik 1969-1999 [diss] (Örebro: Örebro univ., 2016), 30-31, 77-98, 218-20; Christian Lundahl, Viljan att veta vad andra vet: kunskapsbedömning i tidigmodern, modern och senmodern skola [diss.] (Uppsala: Uppsala universitet, 2006), 254, 27783; Alfred Oftedal Telhaug et al., "The Nordic Model in Education: Education as Part of the Political System in the Last 50 years," Scandinavian Journal of Education 50, no. 3 (2006), 248-56.

3 Johan Prytz and Johanna Ringarp, "Local Versus National History of Education. The Case of Swedish School Governance, 1950-1990," in Transnational Perspectives on Curriculum History, ed. Gary McCulloch, Ivor Goodson and Mariano González-Delgado (London: Routledge, 2019), 13435 . 
started to become more decentralised in various ways. A guiding principle, though, was that the state would still determine goals, but the municipalities, the schools, and the teachers were given the responsibility to find, specify, and plan for the means to reach these goals. This approach was in contrast to the prevailing system where the state specified both the goals as well as the means of obtaining these goals. ${ }^{4}$

The shift in governance policy also involved the teaching (i.e., ideological governance) and a central object in this respect was the national school subject curricula. The idea behind the new 1980 curriculum was to give teachers more freedom of choice with respect to content and teaching methods. This autonomy was supposed to entail a less detailed curriculum, ${ }^{5}$ and there are indeed many examples of this change: the syllabi contained prescriptions for what the students were supposed to learn in year spans 1-3, 4-6, and 7-9 rather than prescriptions for each nine years as was the case for earlier curricula.

However, there were deviations from the ideal of decentralisation. The 1980 curriculum was supposed to be in line with a policy of governance by goals, a key idea of the Swedish decentralisation agenda, but that policy was not pursued completely. Lindensjö and Lundgren have claimed there were "interesting" differences between the principles for designing the curriculum and the produced curriculum. ${ }^{6}$ For example, in the actual curriculum, the difference is obvious on a superficial level as the mathematics syllabus contained both goals (i.e., what the students should learn) and clear guidelines about how the teaching was supposed to be carried out. A genuine goal-oriented curriculum was first issued in $1994 .^{7}$ Thus, in comparison, the 1980 curriculum represents a more centralised mode of governance. However, Lindensjö and Lundgren have not revealed in what way the interesting differences in curriculum design were significant. For example, did it affect the student results, the outcome of the teaching? And as far as I know, this has not been studied.

In general, little historical research is available that shows how changes in the design of Swedish curricula have affected the objects these documents were supposed to govern, that is teachers and students. Here it is important to note that the notion of design concerns how the ideological content is structured rather than the content per se. There are several historical studies on school subjects and reforms in the twentieth century where teaching materials and syllabi form an essential part of the material studied. For example, Hultén and Östman have studied the sciences, ${ }^{8}$ Bronäs and Nordmark have studied the social science subject, ${ }^{9}$ Alvén and Gus-

4 Börjesson (2016), 100, 146; Skott (2011), 333-35; Lindensjö and Lundgren (2014), 93-100; Lundahl (2006), 278-81, 359.

5 Skott (2011), 334; Lindensjö and Lundgren (2014), 82-84; Lundahl (2006), 375.

6 Lindensjö and Lundgren (2014), 83-84.

7 Lindensjö and Lundgren (2014), 101-6.

8 Magnus Hultén, Naturens kanon: Formering och förändring av innehållet $i$ folkskolans och grundskolans naturvetenskap 1842-2007 [diss.] (Stockholm: Stockholms universitet, 2008); Leif Östman, Socialisation och mening: No-utbildning som politiskt och miljömoraliskt problem [diss.] (Uppsala: Uppsala universitet, 1995).

9 Agneta Bronäs, Demokratins ansikte: en jämförande studie av demokratibilder i tyska och svenska samhällskunskapsböcker för gymnasiet [diss.] (Stockholm: Stockholms universitet, 2000); Jonas Nordmark, Med en framtida demokrat som adressat: Föreställningar om framtid i svenska samhällskunskapsböcker 1992-2010 [diss.] (Västerås: Mälardalens högskola, 2015). 
tafsson have studied history, ${ }^{10}$ and Englund has studied history and social science. ${ }^{11}$ However, these studies focus on ideological content rather than curriculum design, other aspects of governance, or student results.

Nevertheless, some studies have placed more focus on school subjects and how governance were executed, such as Johnsson Harrie's and Åström Elmersjö's examinations of how the state reviewed textbooks between 1938 and $1991 .^{12}$ Johnsson Harrie has focused on social sciences and Åström Elmersjö has focused on history. However, these authors have not considered how the state's mode of governance affected student achievements.

My description of the field is confirmed by a recent overview concerning Swedish research in curriculum theory, where studies have often included a historical perspective; in the overview, governance on school subjects is not an issue. ${ }^{13} \mathrm{~A}$ similar picture emerges in a study by Gustavsson and Blömeke where they, among other aims, have sought to explain the improved Swedish results in international tests between 1964 and 1995. Although they have considered a number of factors, curriculum design is not mentioned. ${ }^{14}$

As for Gustavsson and Blömeke's study, my study makes two more specific contributions. They have not sorted out which factors influenced the improvement in international tests as they present only a general hypothesis concerning Sweden: "Common performance improvement was due to the combined effect of different measures taken to improve the school." ${ }^{15}$ In this study, I cannot exclude measures or factors as not significant, but my study shows that stronger framing of mathematics in the curriculum could have been one of those measures. My results also problematise the notion of combined effects. Stronger framing of a school subject does not fit the idea of a school system being decentralised.

\section{Theory and method}

As to the aim of describing the design of the curricula of arithmetic and algebra as well as textbooks, the analysis of the material is based on Bernstein's (1974) theory on classification and framing of educational knowledge. ${ }^{16}$ From this theory, I have chosen a number of basic concepts, which are understood in the following way.

10 Fredrik Alvén, Tänka rätt och tycka lämpligt: Historieämnet $i$ skärningspunkten mellan att fostra kulturbärare och förbereda kulturbyggare [diss.] (Malmö: Malmö högskola, 2017); Jörgen Gustafsson, Historielärobokens föreställningar: Påbjuden identifikation och genreförändring $i$ den obligatoriska skolan 1870-2000 [diss.] (Uppsala: Uppsala universitet, 2017).

11 Tomas Englund, Samhällsorientering och medborgarfostran i svensk skola under 1900-talet (Uppsala: Uppsala universitet, Pedagogiska institutionen, 1986).

12 Anna Johnsson Harrie, Staten och läromedlen: En studie av den svenska statliga förhandsgranskningen av läromedel 1938-1991 [diss.] (Linköping: Linköpings Univ., Inst. för beteendevetenskap och lärande, 2009); Henrik Åström Elmersjö, En av staten godkänd historia: Förhandsgranskning av svenska läromedel och omförhandlingen av historieämnet 1938-1991 (Lund: Nordic Academic Press, 2017).

13 Eva Forsberg et al., "Curriculum Code, Arena, and Context: Curriculum and Leadership Research in Sweden," Leadership and Policy in Schools 16, no. 2 (2017), 357-82.

14 Jan-Eric Gustafsson and Sigrid Blömeke, "Development of School Achievement in the Nordic Countries During Half a Century," Scandinavian Journal of Educational Research 62, no. 3 (2018), 402.

15 Gustafsson and Blömeke (2018), 402.

16 Basil Bernstein, Class, Codes and Control, Vol. 1: Theoretical Studies Towards a Sociology of Language, 2. rev. ed. (London: Routledge, 1974), 202-6. 
Classification refers to how the content of teaching is organised in categories, their boundaries and relations between the categories. The set of school subjects we find in the curriculum is an example of such categories. With respect to school subjects there are two types of classification: external and internal. External classification concerns the relations between a subject and other subjects as well as everyday practices. Internal classification is about the relation and boundaries between the topics within the subject, for instance, arithmetic and algebra in school mathematics. Content refers to the set of values, concepts, facts, skills, competencies, etc. the teachers are supposed to concentrate their teaching towards. ${ }^{17}$

Framing refers to the means of communication and is about boundaries since the selection of the means of communication sets boundaries for what can be taught and to what extent. The analysis of framing is focused on organisation and pacing. That is, the basic elements that regulate the communication in the teaching process.

In this study, organisation is about in which order or sequence different subtopics, for instance fractions and decimal numbers, occur in the teaching processes. In the presented analysis, I also use the word sequencing to describe this phenomenon. $\mathrm{Pa}$ cing or pace is about speed, time, and extensiveness of what the students are supposed to learn. Basic issues in this respect are usually understood as questions: When is a subtopic, for instance, fractions, introduced and how much does the subtopic comprise and for how long is it taught?

According to Bernstein, an analysis of the classification and framing of school subjects ends in an evaluation of boundaries as clear or blurred, strong or soft. In brief, strong classification and framing means that a text contains clearer or more explicit directives about what to teach and how to communicate; weak indicates the opposite character of the directives. Moreover, a subject or a topic can be characterised as more or less insulated in relation to other subjects or topics, but also everyday activities. Much insulation means that two topics have little in common, for instance the same concepts and expressions are not used to describe the content of the topics or it is not described how the two topics relate to each other.

On the basis of these concepts, the following questions have been formulated:

1) How were the topics of arithmetic and algebra classified and framed in the curriculum and in the textbooks?

2) How did classification and framing change over time in the textbooks?

3) In what respect was arithmetic and algebra classified and framed differently?

I have not used any pre-set and more specific criteria for how classification, framing and different levels thereof are achieved. Instead, an important part of the analysis has been to describe how the latter was achieved. This also means that the analysis in the first place concerns how categories and boundaries are maintained. The content of the subjects is by no means irrelevant, but secondary in the analysis. Consequently, in the chapters of this article, it is the way categories and boundaries are set up and organised that stands in the foreground.

The material for the analysis of the curriculum comprises the mathematics syllabus from 1980 and the commentary material, diagnoses, and national tests (Standardprov)

17 Bernstein (1974), 203. Bernstein defines content in a more general manner: "How the period of time is used." My definition is focused on what knowledge and values the teachers are supposed to spend time on when teaching. 
connected to the syllabus. ${ }^{18}$ The syllabus was in effect until the first (spring) semester of 1995 and was successively replaced over three years after the summer of $1995 .{ }^{19}$ The data for TIMSS1995 were collected during the spring semester of 1995 . This means that the Swedish students in TIMSS1995 for all of their time in school had followed the syllabus from 1980 .

A rather large sample of textbook series has been selected that covers the whole period. In total, 19 brand new textbook series intended for years 4-6 and 19 brand new textbook series intended for years 7-9 were published between 1979 and $1994 ;{ }^{20}$ I have analysed six of these for years 4-6 and seven for years 7-9. To strengthen my conclusions, I have selected series authored by established authors or authors who became established. By established, I mean that the author(s) regularly and over a long period have had brand new textbooks published or old textbooks significantly revised between 1970 and 2000. I assume that profit seeking publishing companies would not reinvest in authors if their previous textbooks were not at least fairly popular. Thus, on the basis of this single assumption, it is plausible that textbooks authored by established authors also were the more popular textbooks. Of course, this is a crude measure were authors can be placed in two or possibly three groups.

The selected textbooks were part of a database containing all Swedish textbooks in mathematics between 1930 and 2014. The data come from LIBRIS, the joint catalogue of the Swedish academic and research libraries, and contains all published textbooks since $1976 .{ }^{21}$ An algorithm was constructed to identify when each author published a brand new textbook. On the basis of this information, I identified the established authors. ${ }^{22}$

Table 1. Selected textbook authors, years 4-6

\begin{tabular}{|l|l|l|l|}
\hline Authors & Title of series & Ed. & Year of first publ. \\
\hline Undvall & Matematikboken 4-6 & 1 & 1979 \\
\hline Skoogh et al. & Räkneresan A-F & 1 & 1986 \\
\hline Undvall & Matematikboken 4-6 & 3 & 1987 \\
\hline Undvall & Alma A-C & 1 & 1992 \\
\hline Rockström & Matematik för mellanstadiet 4a-6b & 2 & 1993 \\
\hline Skoogh et al. & Räkneresan X2001-3 & 1 & 1995 \\
\hline
\end{tabular}

Of the series in Table 1, at least one of their authors belong to the top ten list of authors who for the longest period continually produced brand new textbooks

18 See the list of sources at the end of the article.

19 Utbildningsdepartementet, Läroplaner för det obligatoriska skolväsendet och de frivilliga skolformerna: Lpo 94 : Lpf 94 (Stockholm: Utbildningsdep., 1994), 4.

20 For numbers of published textbooks series, see Johan Prytz, The Construction of a Database Regarding Swedish Historical Textbooks in Mathematics (grades 1-9), 1900-2015: A Technical Description (Uppsala: Uppsala universitet, 2016), 15.

21 To search in LIBRIS for textbooks published after 1978 and to have a reliable result is relatively easy. LIBRIS was created in 1976 and from the beginning "teaching materials" (läromedel) was a category, which of course included textbooks. Thus, a search for "teaching materials" and "mathematics" will return all books classified as textbooks and mathematics since 1976.

22 For further information about the database and its construction, see Prytz (2016). 
between 1970 and 2000 and who was published between 1979 and 1995. Debuting in 1976, Undvall is number one. Nilsson, who is a co-author with Skoogh et al., is in fourth and Rockström is in sixth place.

Table 2. Selected textbook authors, years 7-9

\begin{tabular}{|l|l|l|l|}
\hline Authors & Title of series & Ed. & Year of first publ. \\
\hline Alvin & Sjuans-Nians matematik & 1 & 1979 \\
\hline Undvall & Matematikboken för högstadiet Sk 7-9 & 2 & 1979 \\
\hline Mårtensson et al. & BETA Högstadiets matematik Åk 7-9 & 1 & 1982 \\
\hline Undvall & Matematikboken för högstadiet 7-9 S & 1 & 1985 \\
\hline Mårtensson et al. & BETA Högstadiets matematik Åk 7-9 & 3 & 1988 \\
\hline Skoogh et al. & Möte med matte A-F & 1 & 1989 \\
\hline Undvall & Matematikboken för högstadiet 7-9 ABC & 1 & 1991 \\
\hline
\end{tabular}

Of the series in Table 2, at least one of the authors belong to the top ten list of authors who for the longest period continually produced brand new textbooks between 1970 and 2000 and who was published between 1979 and 1995. Debuting in 1976, Undvall is number one. Mårtensson is in second, Alvin is in fourth, and Skoogh is tenth place.

Skoogh is a borderline case as to years 7-9, but he is relevant since he was responsible for mathematics education (1-9) at the National Board of Education in the late 1970 s and early 1980s. In addition, he was involved in writing the mathematics syllabus and the commentary material. Thus, he was an established figure in Swedish school mathematics before he began writing textbooks.

More exact figures about the popularity of the textbooks between 1979 and 1995 are not available. However, a governmental investigation about textbooks used a more rigorous approximation of the use of different textbooks for the school year $1987 / 88 .{ }^{23}$ For years 4-6, Undvall's books belonged to the top four for each three years with a frequency between 10.6 to 25.1 per cent. The greatest frequency of all books was 35.3 per cent. The frequencies of the books by Skoogh et al., which had been published only a year before, were low (3.8 per cent) and used only in year 4 . As for years 7-9, Undvall's books belonged to the top two for each three years with a frequency between 17.7 and 54.5 per cent. After adding the frequencies of both of his series, the numbers are 21.1 to 54.5 per cent. The greatest frequency of all books was 54.5 per cent. Alvin and Mårtensson et al.s books had lower frequencies: Alvin scored between 0 and 24.5 per cent and Mårtensson et al. between 5.4 and 8.6 per cent. Due to a small number of investigated classes, in particular for years 7-9, these numbers should be considered with care. ${ }^{24}$

The analysis of textbooks does not include years 1-3 because the student results discussed in the article stem from tests for the years 7-10. That is, to explain these re-

23 Läromedelsöversynen, Skolböcker: Rapport från Läromedelsöversynen 2. 400 klasser i grundskolan (Stockholm: Allmänna förl., 1988), 43-44.

24 Ibid. The variation of a book series across the school years is probably related to the small number of investigated school classes: 32 to 37 classes per school year in year 4-6 and only 8 to 11 classes per school year in year 7-9. 
sults, it is sufficient to just include textbooks from years 4-9. As for the textbooks for years 7-9, only the textbooks intended for the advanced course have been studied. ${ }^{25}$

Regarding the second aim - to examine if differences in the design of the curricula of arithmetic and algebra can explain differences in SIMS and TIMSS results in those two topics - my ambition is not to give a complete and final explanation but to provide arguments for what can explain differences in the results. I have three basic arguments to why my explanation has a certain degree of validity. First, the two tests corresponded very well with the 1980 syllabus - that is, the great majority of the items categorised as arithmetic and algebra in both tests fits the corresponding categories in the syllabus. ${ }^{26}$ Second, it is possible to reduce the problem of changing contexts and effects of other causes. ${ }^{27}$ That is, different results in the two topics are much less likely to be explained by differences related to teacher pedagogy, background, and experience as the students had the same teachers for both topics. In addition, general factors concerning, for example, economy, general policies of governance, and pedagogical trends alone cannot explain the differences because arithmetic and algebra were taught under the same circumstances. However, I cannot exclude that these types of general factors might have been necessary conditions for the positive development of the arithmetic results. Nonetheless, such factors were not sufficient conditions for the positive development in arithmetic. Third, and on the basis of the two previous arguments, the case is suited for analysing a causal relation. That is, if, for example, different levels of framing can be associated with the two different student results, there is support for a causal relation between levels of framing and improved results.

The weakness of this explanation, presented thus far, is that is does not include a description of the process from issuing the curriculum to student results 15 years later. What happened in that process must also support the conclusion of a causal relation. To corroborate my conclusion in this respect, I analyse popular textbooks from the period in question. It is more reasonable to conclude that the curriculum design affected the student results if the textbooks used in classrooms changed in a way that is consistent with my results regarding classification and framing in the curriculum. Of course, however, other elements are possible in the process from curriculum to student results, for example, teachers' in-service training and teacher education. These processes can be objects of future studies.

\section{Background}

The period between 1980 and 2000 can in some respects be considered a golden age of the Swedish school system (years 1-9), at least as reflected in results of international tests for the subjects Swedish, Mathematics, and Science. The results peaked in the mid1990s, but it was not until after the year 2000 that the results began to decrease at a very fast rate. ${ }^{28}$

As regards to school mathematics between 1980 and 1995, the over-all picture is positive as reflected in the national tests from that period and the two international

\footnotetext{
25 There were two types of courses: advanced and general.

26 See Appendix A for further details.

27 Cf. Skolverket, Vad påverkar resultaten i svensk grundskola? Kunskapsöversikt om betydelsen av olika faktorer: sammanfattande analys (Stockholm: Skolverket, 2009), 130.

28 Skolverket (2009), 78-79.
} 
tests in 1980 and $1995 .{ }^{29}$ The standard tests were made in year 9, the international test in 1980 (SIMS) was made in year 7, and the 1995 test (TIMSS) was made in grades 6 and 7 and on a smaller scale in grade 8 . In contrast, the student results in the 1970 s had stagnated, both in international and national tests. ${ }^{30}$

The stagnation of the student results in the 1970 s occurred in a time of contradictory governance of school mathematics. The 1969 syllabus, along with the commentary material, prescribed a radically new type of mathematics teaching based on the so-called New Math. However, by 1973, the central school authorities issued a complementary commentary material that downplayed the importance of New Math; the focus was now on arithmetic and quite traditional teaching methods. ${ }^{31}$ In that sense, this complementary commentary material was rather similar to the 1980 syllabus and its commentary material. However, these new commentaries did not replace the syllabus and previous commentaries, so two governmental documents existed prescribing two types of mathematics teaching. This ambiguous situation resulted in two types of textbooks in the 1970s: those in line with New Math and those in line with more traditional pedagogy. ${ }^{32}$ This contradictory situation ended with the launch of the 1980 curriculum, which contained nothing of New Math. Since 1980, student results improved.

However, the results between 1980 and 1995 were not unequivocally positive. In 1980, the results from the international test for arithmetic, algebra, geometry, and statistics were on the same level, which by international comparison was low. In 1995, the results had improved significantly although the improvement occurred mainly in arithmetic. ${ }^{33}$ In algebra, geometry, and statistics, improvements were considerably smaller. ${ }^{34}$ In the 1995 test, the items were categorised slightly differently. Proportionality, which was part of arithmetic in the 1980 test, formed its own category. The results in this category were at the same level as algebra, that is, on a low level. ${ }^{35}$ As mentioned, these studies were made mainly in years 6 and 7 but also in year 8 in 1995. The results were confirmed by a study of the pre-knowledge of students in the theoretical programmes in the upper secondary schools in the late 1980s. The study shows that the knowledge of arithmetic was good, but the results in algebra were worse, even among students who had attended the advanced course in years $7-9 .{ }^{36}$

29 Skolverket (2009), 57, 67.

30 Cf. Johan Prytz, "The New Math and School Governance: An Explanation of the Decline of the New Math in Sweden," in Researching the History of Mathematics Education. ICME-13 Monographs, ed. Fulvia Furinghetti and Alexander Karp (Cham: Springer, 2018), 206-8.

31 Cf. Prytz (2018), 203-5. The title of the complementary commentaries was Basfärdigheter $i$ matematik [Basic skills in mathematics].

32 Cf. Prytz (2018), 205-6.

33 Skolverket (2009), 67.

34 Cf. W. J. Pelgrum et al., The Implemented and Attained Mathematics Curriculum: A Comparison of Eighteen Countries. Second International Mathematics Study. Contractor's Report (Enschede: Twente University of Technology, 1986), 8; Albert E. Beaton et al., Mathematics Achievement in the Middle School Years. IEA's Third International Mathematics and Science Study (TIMSS) (Chestnut Hill: TIMSS International Study Center, Boston College, 1996), 41.

35 Beaton et al. (1996), 41. In Pelgrum et al. (1986) there are no readymade statistics about proportionality. But if we consider the solution frequencies of the six items concerning proportions, the average is on the same level as the average of all arithmetic items. The items are item 12, 33, 56, 98, 110, and 128 in Appendix A, Table 3.

36 Bengt-Olov Ljung et al., Översiktsdiagnos i matematik inför skolstarten på treåriga gymnasielinjer (Stockholm: Högskolan i lärarutbildning i Stockholm, Institutionen för pedagogik, 1991), 83. 
In the Swedish main report on TIMSS, the low result in algebra is explained with reference to many of the algebra items being treated at the end of year 8 and year 9 (i.e., after the TIMSS test). A second explanation is that the Swedish curriculum emphasised everyday knowledge rather than algebra. ${ }^{37}$

What seems to be a paradox is that the national evaluation of Swedish school mathematics (7-9) published in 1992 did not indicate any particular problems related to algebra. ${ }^{38}$ The evaluation of the students' level of knowledge was based on national tests in year 9. However, a survey of the teachers, which was a part of the evaluation, indicates that algebra was one of the topics where the students were less prone to succeed. ${ }^{39}$ In this article, I will show that this paradox may be related to how the national tests were constructed: in the national tests, algebra was not a specific area to be tested and there were quite few algebra items.

In conclusion, TIMSS and other tests gave clear indications of improved results in arithmetic for the period 1980-1995, but not in algebra. In this article, I examine whether the design of the curriculum had something to do with these differences. I begin with the syllabus and the commentary material.

\section{Classification in syllabus and commentary material}

The overall conclusion about arithmetic and algebra in the syllabus and the commentary material is that the classification of both topics was strong. Moreover, the two topics were insulated from each other, especially in years 1-6; that is, the attempts of integration were few and unclearly described.

The basic observation about strong classification of arithmetic and algebra is that both topics were addressed as specific areas in the 1980 syllabus as well as in the corresponding commentary material. Interestingly, algebra was not a separate topic, but associated with functions and the heading in the syllabus was "Algebra and functions" (Algebra och funktionslära). Arithmetic, on the other hand, was divided on three areas with the headings "Basic arithmetic" (Grundläggande aritmetik), "Real numbers" (Reella tal), and "Percentage" (Procent). These headings were on the same level and denoted "Main elements" (Huvudmoment). The other main elements in the syllabus were "Problem solving" (Problemlösning), "Measurements and units" (Mätningar och enheter), "Geometry" (Geometri), "Descriptive statistics and probability" (Beskrivande statistik och sannolikhetslära), and "Computer" (Datalära). ${ }^{40}$ Here we should recall how proportionality became a separate category in TIMSS1995. In the 1980 syllabus, proportionality did not constitute a separate category. In fact, the word proportionality (proportionalitet) was only mentioned once, and then in connection with linear functions. The related word proportion (förhållande) was not used at all. ${ }^{41}$ Thus, proportionality had weak classification in the syllabus.

37 Skolverket, TIMSS: Svenska 13-åringars kunskaper $i$ matematik och naturvetenskap $i$ ett internationellt perspektiv (Stockholm: Statens skolverk, 1996), 48, 85.

38 Skolverket, Den nationella utvärderingen av grundskolan våren 1992: Matematik, Åk 9, Huvudrapport (Stockholm: Statens skolverk, 1993), 72-76.

39 Skolverket (1993), 66.

40 Skolöverstyrelsen (SÖ), Läroplan för grundskolan, Allmän del: Mål och riktlinjer, kursplaner, timplaner (Stockholm: LiberLäromedel/Utbildningsförlaget, 1980), 80.

41 This circumstance was also reflected in the commentary material. The words proportionality and proportion were used only a few times each. 
For the sake of brevity, I will use the expressions arithmetic and algebra unless otherwise noted. Thus, my term arithmetic covers the three main elements related to arithmetic mentioned above. For algebra, I also include functions.

The division into main elements was reused in the commentary material, but new distinctions were also introduced. Each main element was further divided into two types of elements: necessary and desirable. This division occurred only in the commentary material. ${ }^{42}$ These two types of elements were flexible in the sense that what was desirable, for example, in years $1-3$, was necessary in years $4-6$. I return to this in the section "Framing in syllabus and commentary material."

Of the main elements mentioned above, "Problem solving" had a special status. It was supposed to be integrated in all other main elements rather than a topic taught separately. Both the syllabus and in the commentary material provided some general characteristics of what constitute a problem and different phases in the problem solving process.

The conclusion that the classification of arithmetic and algebra can be considered strong is also based on the use of language. In this case, strong classification refers to the relation to other school subjects, but also everyday language, that is external classification. The language of the syllabus and the commentary material was clearly mathematical as a lot of words for mathematical objects, relations, or operations were used. By mathematical objects I mean objects related to quantity, for instance numbers; by relations I mean relations between quantities, for instance equations; and by operations I mean the handling of the objects and relations, for instance computations and solving equations. Examples are given in the section "Framing in syllabus and commentary material."

Thus far, only the external classification has been treated. Now I will turn to the internal classification. The relation between arithmetic and algebra, as expressed in the syllabus and the commentary material, was insulated, especially in years 1-6. That is, the internal classification was strong. One set of arguments for this conclusion concerns how often the relation between the topics was explicitly expressed. In the syllabus, this relation was mentioned only once. Square roots, which belonged to the main element "Real numbers," should also be treated in connection to solving second degree equations. ${ }^{43}$ Notice that second degree equations appeared in the ninth and final year of Grundskolan. In the commentary material, however, the relation between arithmetic and algebra was mentioned a bit more often, but still not very often. The sections on real numbers and rational numbers stressed the importance that the students in later algebra studies should understand how the rules of arithmetic apply to all types of numbers. ${ }^{44}$ In fact, it was stated that knowledge in calculations with fractions "perhaps" was the most important knowledge for being able to work with algebra. ${ }^{45}$ But the task to train calculation with fractions was concentrated to years $7-9$, according to the syllabus. ${ }^{46}$ Actually, the commentary material advised

42 Skolöverstyrelsen (SÖ), Läroplan för grundskolan, Kommentarmaterial, Att räkna: En grundläggande färdighet (Stockholm: LiberLäromedel/Utbildningsförlaget, 1982), 7.

43 SÖ (1980), 102.

44 SÖ (1982), 31-33.

45 SÖ (1982), 33.

46 SÖ (1980), 102. 
teachers of years 1-6 to transform fractions and root expressions to decimal numbers, sometimes approximations, so that the computations should become easier. ${ }^{47}$ According to the commentary material, fractions occurred also as constants in connection with linear equations ${ }^{48}$ yet another topic that occurred only in years $7-9 .{ }^{49}$

However, there were other attempts in the commentary material to integrate arithmetic and algebra, but they were vague and not extensive. The sections about algebra and functions in the commentary material mentioned algebra in the earlier years (1-6) as a part of arithmetic. ${ }^{50}$ This integration only involved one type of task: equalities where numbers are left out, an elementary type of equation. Although no examples of such equalities were given, I assume, on the basis of textbooks, the commentary material was referring to tasks of the following types: $a_{-}^{*}=b$ or ${ }_{-}^{*} a=b$, where ${ }^{\star}$ denotes an arithmetical operation and where $a$ and $b$ are numbers. ${ }^{51}$ According to the commentary material, the students should also write stories for these types of equalities. These types of tasks were supposed to enhance the students' understanding of variables and the relation between addition-subtraction and multiplication-division. Yet another type of task on this theme was to let students formulate tasks for each other with the idea that these tasks facilitate reflections about new types of numbers other than positive integers, properties of numbers, and the meaning of the rules of arithmetic. ${ }^{52}$ Thus, one single type of task (equalities with missing numbers) was ascribed great potential for learning algebra; however, it was not clear which properties and meanings were intended as neither the syllabus nor the commentary material provided a cohesive and exhaustive account of the matter. Therefore, despite some integration of arithmetic and algebra, the general picture is that the relation between arithmetic and algebra was insulated.

It could be argued that the commentary material implicitly addressed integration in the sections about algebra and functions in years 7-9. ${ }^{33}$ Various passages mentioned concepts central to arithmetic, more precisely arithmetical operations, negative numbers, rules of priority, and the communicative, associative, and distributive laws. However, rules of priority and the communicative, associative, and distributive laws were only mentioned in the sections about arithmetic in years 7-9, and the same teachers did not teach in the years 1-3, 4-6, and 7-9. For these reasons, I find this type of implicit integration restricted to the years 7-9.

Another set of arguments of why arithmetic and algebra were insulated from each other concerns the concept of everyday knowledge. The syllabus as well as the commentary material emphasised knowledge useful in everyday life. Moreover, there was a clear distinction between knowledge useful in everyday life and other types of knowledge. Arithmetic fell in the former category and algebra in the latter.

According to syllabus, the primary goal of the mathematics courses Grundskolan (19) was that the students should acquire the ability to solve every day mathematical pro-

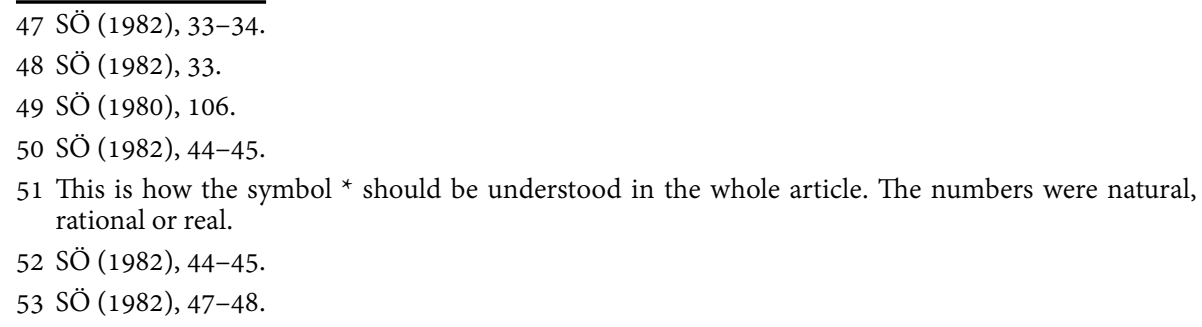


blems. The justification for this goal was the more general goal of preparing students for adult citizenship. The mathematics that met this primary goal was arithmetic, measuring, and some practical geometry and statistics. ${ }^{54}$

A secondary goal was that the students should acquire knowledge and skills in mathematics necessary for studies in other school subjects, further studies after Grundskolan, leisure time, and working life. ${ }^{55}$ Thus, early on in the syllabus there was a distinction between knowledge useful in everyday life and knowledge useful outside everyday life. Algebra and functions belonged to the latter. ${ }^{56}$ This separation of arithmetic and algebra on the basis of everyday knowledge was again accentuated at the beginning of each of the sections about arithmetic and algebra. The very first sentences read as follows:

\footnotetext{
The teaching in arithmetic should be based on and rooted in everyday problems and, for the students, concrete situations. ${ }^{57}$

[Algebra and functions] are of less importance in everyday life, but all students should have some information about the matter. ${ }^{58}$
}

As regards to the insulation of arithmetic and algebra, the overarching topic "problem solving" contributed further to this division. According to the syllabus, the problems should be of the type encountered at home and in society. Society is broad concept that can include further studies and consequently also involve algebra or algebra as an integrated part of arithmetic. However, the section on problem solving clearly stated that much attention should be paid to practical problems in everyday life. ${ }^{59}$ This view was also emphasised in the commentary material. ${ }^{60}$

In the commentary material, however, the notion of problem solving was further developed and it was established that problem solving also included mathematically oriented problems such as those found in algebra. Nonetheless, this was stated with clear reservations: only a certain amount of time should be spent on such problems and only certain students should engage in these types of problems. Moreover, students who had not acquired the so-called everyday skills should not work with that type of advanced content. ${ }^{61}$ But then again, according to the commentary material, everyday problems were the most important in the new syllabus. It was also noted that this constituted a change in relation to previous syllabi where more mathematically oriented problems had been recommended. ${ }^{62}$

\section{Framing in syllabus and commentary material}

Arithmetic and algebra were framed differently in the syllabus and in the commentary material. Arithmetic had a relative strong framing, whereas algebra had a relative weak framing, especially in years 1-6.

\footnotetext{
54 SÖ (1980), 98.

55 Ibid.

56 Ibid.

57 SÖ (1980), 100.

58 SÖ (1980), 105.

59 SÖ (1980), 100.

60 SÖ (1982), 16.

61 SÖ (1982), 22.

62 SÖ (1982), 16.
} 
I begin with the framing of arithmetic in the syllabus and the part of framing that concerns order and sequence. The sequencing of arithmetic was expressed explicitly and precisely. For the years $1-3,4-6$, and 7-9, but not for each year, the syllabi provided relatively detailed descriptions of the knowledge the students were supposed to acquire: types of numbers (natural numbers, whole numbers, rational numbers and real numbers); intervals (e.g., 0-100 before 0-1000), which tables in addition, subtraction, multiplication and division the students should master; number of decimals; and how many figures the numbers should be expressed with when the students applied algorithms. ${ }^{63}$

An important detail in the sequencing of arithmetic was that the same terminology appeared on each level. For instance, in years 1-3, the multiplication tables should not involve factors greater than five and in years 4-6 there were no such restrictions for multiplication tables. Another example concerns the number of digits the factors should contain when working with multiplication algorithms: early in years 1-6, one of the factors should be single digit and later in years 1-6, both factors could be multi digit. ${ }^{64}$

In summary, the syllabus authors used precise mathematical terms to formulate a precise and coherent syllabus of arithmetic. These formulations were brief as nine school years were covered in about three pages. I see this precision and coherence as an example of strong framing.

However, these formulations with relative high level of detail in the 1980 arithmetic syllabus did not cover several aspects of the knowledge concept. On the contrary, this part of the syllabus focused on a small set of skills or abilities related to calculation and the mastering of algorithms. Apart from calculation, there were mental calculations (huvudräkning) and rough estimates (överslagsräkning). Other skills and abilities were specified in the syllabus, but in an indirect way via the main element "Problem solving." Since "Problem solving" is an overarching element, it also involves arithmetic. "Problem solving" was divided into three phases: to understand a problem; to master the numerical calculations; and to analyse, evaluate, and draw conclusions from the results. However, these abilities were not developed into a sequence in three year spans. Moreover, the description was quite general: the sequencing of problem solving concerned the nature of the problems and how they developed from the concrete to the more abstract. ${ }^{65}$

In comparison to arithmetic, algebra was weakly framed in the syllabus, especially in years 1-6. The basic argument is that the formulations about algebra were brief and had few details. The sequencing was done in less than one page. Years 1-3 just concerned simple equalities (enkla likheter), which should be solved through testing. For years 4-6, the formulation was a little different: the students should solve simple equations (enkla ekvationer) through testing and start off by solving problems. The concept of function was introduced in years 4-6 through experiments and graphs. The students were also supposed to handle formulas. ${ }^{66}$ In addition, as mentioned above in connection to classification, neither the syllabus nor the commentary material contained further information about what the students were supposed to learn

63 SÖ (1980), 100-3.

64 SÖ (1980), 101-2.

65 SÖ (1980), 100.

66 SÖ (1980), 105-6. 
in algebra beyond the skill of solving simple equalities and equations in years 1-6.

In contrast, the description of algebra in years 7-9 contained more details in terms of the number of expressions with a specific meaning. The whole description in the syllabus is quoted below:

\begin{abstract}
Interpretation and construction of graphs in the whole coordinate system. Formulating, simplifying and calculating expressions. Parenthesis expressions, breaking out of factors as well as the square rules and conjugate rule are treated, but with particular consideration for the students' maturity, interest and needs. Equations of the first degree, also with unknown on both sides, as well as parenthesis and fractions. Problem solving with simple equations. Linear functions, especially those that indicate proportionality. Linear equation systems and simple second degree equations, mainly in problem solving and preferably with graphical solution. ${ }^{67}$
\end{abstract}

Thus, algebra in years 7-9 had a stronger framing in the syllabus than in years 1-6.

As to proportionality and framing, proportionality was dealt with very briefly in both the syllabus and the commentary material. In addition, it was scattered in several topics: arithmetic, algebra, and probability and statistics. ${ }^{68}$ Proportionality must therefore be regarded as weakly framed.

A second argument about weak framing of algebra concerns the reappearance of terms in the descriptions. Most of the terms in the description for years 7-9 (see quotation above) did not appear in the descriptions of algebra for years 1-6. For example, simplifying expressions using parenthesis and breaking out factors were not a prescribed part of algebra in years 1-6. These terms, however, did occur in the description of arithmetic for years 7-9, but not in the description of arithmetic for years $1-6 .{ }^{69}$ Thus, in comparison to arithmetic, the syllabus authors, to a much lesser degree, used precise mathematical terms to formulate a precise and coherent syllabus of algebra for the years 1-9. As with the arithmetic syllabus, the algebra syllabus said little about skills, abilities, and the understanding of concepts.

In comparison with the syllabus and the sequencing of arithmetic and algebra, the commentary material did not bring more detailed sequences such as detailed lists of what the students should achieve each year. Rather, the commentary material contributed with principles for sequencing and pacing and provided concrete examples.

For arithmetic, these general principles where the following: $:^{70}$

The teaching should start with everyday problems and concrete situations.

At the same time, the students need to have systematic training of skills in arithmetic. This training should aim at accuracy (säkerhet) and speed.

A student may not begin with a new area without demonstrating the foundation from previous areas.

These principles were further specified with respect to tables (addition, subtraction, multiplication, and division), rational numbers, and percentage. ${ }^{11}$

In contrast to the syllabus, the commentary material and the sections on arithme-

67 SÖ (1980), 106.

68 In the commentary material it was explained in the section on fractions that it concerned proportionality, but that the latter concept was now mainly dealt with in other areas such as linear equations, percentages and probability theory. SÖ (1982), 33.

69 SÖ (1980), 102.

70 SÖ (1982), 28.

71 SÖ (1982), 28-38. 
tic contained descriptions of how students understand, or misunderstand, concepts and their representations such as how students misunderstand algorithms and fractions. ${ }^{72}$ Nonetheless, there are few paragraphs about the students' understandings, so they can neither be considered exhaustive or coherent.

In algebra, there were fewer general principles: the teaching should be as concrete as possible, preferably with experimental (laborativt) materials and start with problems. ${ }^{73}$ As regards the sequencing of algebra, it was unbalanced with respect to the level of details. In years 1-5, the commentary material did not add much to the syllabus. ${ }^{74}$ However, for years 6 and onwards there were more details about types of exercises and students' understanding of concepts and representations.

Just as in arithmetic, this higher level of details was achieved solely by means of mathematical concepts and representations. For example, in the equation $3 x+2=8$, the students should understand $3 x$ both as a whole $(=6)$ and as two factors ( 3 and $x$ ). Moreover, different meanings of the minus-sign were underscored by the example $-x+1=1-x$. In later years, the level of difficulty of the exercises should be raised by applying the commutative, associative, and distributive laws more frequently. ${ }^{75}$ Here the letter symbols in equations were introduced by the end of the years $4-6$, which I understand as year $6 .^{76}$ Still these equations should primarily be solved by testing.

Despite this higher level of details in years 6-9, which does indicate a stronger framing, I am unable to conclude that the framing of algebra was very high in years 6-9. The commentary material did not specify what years and at what pace the level of difficulty should be increased.

Thus far, the framing of arithmetic (1-9) and algebra (6-9) seems to have been equally strong in the commentary material, but weaker when it comes to algebra in years 1-5. However, there are circumstances that made the framing of arithmetic much stronger.

As regards to sequencing of arithmetic and algebra, the commentary material had clear differences in the level of details. One of the differences was related to a very lengthy example of how two types of elements in the syllabus-necessary and desirable - should be concretised. ${ }^{77}$ The two page example concerned only arithmetic and it exemplified what the two types of elements comprised in each year span (i.e., 1-3, 4-6, and 7-9). The authors applied the same type of detailed descriptions as in the syllabus, but with even more details, as they explained what were the necessary and the desirable elements for the years 1-3, 4-6, and 7-9. As in the syllabus, there were no mentions of other skills or abilities.

Another clear difference in sequencing was of a more indirect nature and concerned methodological directives about individualisation in the commentary material. This was underscored both in the sections about arithmetic and algebra. ${ }^{78}$ As for algebra, individualisation was extra important in years 7-9. The basic idea about individualisation was that each student, as far as possible, should receive teaching suited

72 SÖ (1982), 29, 32, 36.

73 SÖ (1982), 44-46.

74 SÖ (1982), 44-45.

75 SÖ (1982), 45-48.

76 SÖ (1982), 45.

77 SÖ (1982), 7-9.

78 SÖ (1982), 29, 47. 
to his or her needs. ${ }^{79}$ To that end, the central school authorities issued detailed diagnostic tests, which had been developed over ten years in various projects. ${ }^{80}$ However, algebra was not part of this material. The diagnoses covered arithmetic for years 1-9 and geometry and statistics for years 6-9. ${ }^{81} \mathrm{~A}$ small portion of algebra (i.e., formulas for areas and volumes) was covered in the geometry section for year 9 . Thus, there were very detailed guidelines about what students should achieve in each year in arithmetic, but not in algebra.

A third circumstance is that national tests were given only in year 9, in contrast to the 1970s when such tests also were given in years 3 and 6 . This is indeed a place where there were directives related to pacing: How far should the teaching proceed and how extensive should the topics be? I assume the test was not ignored since it provided guidelines about how to evaluate and grade students. So, now it is time to look at how arithmetic and algebra were classified and framed in the national test in year 9.

\section{Classification and framing in the national tests}

The analysis of classification of arithmetic and algebra in the tests is a question of determining how groups of items were labelled. The analysis of framing of arithmetic and algebra is focused on how the test contributed with information about how much the students had learned (i.e., how far the students' learning had proceeded). This issue is, of course, related to how different parts of the tests were classified. If, for example, one part was denoted algebra, the total score on that part provided information about a student's knowledge in algebra. However, the analysis goes further than that as I also considered what types of items and how many were included in each part or subtest. Such features constitute a limit for how much information a subtest could provide.

If just the headings of each subtest are considered, they suggest strong classification for arithmetic and weak classification for algebra. During the whole period, only two explicit themes in each test were identified: arithmetic and problem solving. The term arithmetic was not used, but the term calculation was applied in the heading of at least one subtest in each test. Each test comprised two or three subtests. However, this did not mean that algebra was not included in the test. In fact, each year the tests contained a number of items that involved algebra. ${ }^{82}$

Some general trends are associated with the type of items in the tests. ${ }^{83}$ The most significant trend is the successive decrease in the number of items, from 124 in 1980 to 28 in 1990 and then a slight increase. The decrease was to great degree achieved by reducing the number of items in pure arithmetic. The changes in absolute numbers of items in algebra were more moderate. The great reduction of arithmetic items entailed that the share of algebra items increased considerably. Therefore, from being

79 SÖ (1982), 29, 47.

80 Skolöverstyrelsen, SÖ:s diagnostiska uppgifter i matematik. Metodisk handledning. (1. uppl.) (Stockholm: LiberUtbildningsförlaget, 1983), 6.

81 SÖ (1983), 21-23. Two editions of the diagnosis material were issued, the second in 1988. The second edition did not include a specific section on algebra. Skolöverstyrelsen, SÖ:s diagnostiska uppgifter i matematik. Lärarhandledning; Översiktsdiagnoser med facit [åk] 3-4, [åk] 6-7, [åk] 8-9; Facit till elevhäfte åk 9 (Stockholm: LiberUtbildningsförlaget, 1988), 3-19.

82 See Table 5 in Appendix B.

83 See Table 4 in Appendix B. 
a rather marginal topic in the early 1980s, algebra occupied about 50 per cent of the whole test in the early 1990s, but the items did not increase much in absolute numbers. In this respect, the main increase was between the school years 1984/85 and $1986 / 87$.

Another trend, but more rapid, concerns the distribution of different items on the various parts of the test. Before 1985, the syllabus topic arithmetic was partially separated from algebra; algebra was mainly located in subtest 2 and 3, which were denoted as problem solving. ${ }^{84}$ In total, there were three subtests. In subtest 1 , the few algebra items that did occur were elementary. These items involved formulas, but the solution required only that numbers were plugged into the formulas and what then remained was to calculate the value of the unknown, which was situated by itself on one side of the equal sign. However, in subtest 2 and 3, the syllabus topics arithmetic and algebra were always mixed. Moreover, until 1984/85, part 1 of the test comprised a large number of items in arithmetic. ${ }^{85}$ In connections to these items, the students were supposed to perform simple calculations. This situation changed after 1985, when all subtests contained a mix of items from the syllabus topics arithmetic and algebra. This change included that the number of items in both pure and applied arithmetic was fewer, both in absolute and relative numbers. ${ }^{86}$ Moreover, more complex algebra items appeared in subtest 1 . Since 1989, there were only two subtests.

As regard the framing of the syllabus topic arithmetic in the tests, my conclusions is that it went from strong to less strong. Between 1980 and 1984, the framing was strong in the sense that the test results provided a lot of clear information about the students' achievements in that area; arithmetic was an explicit topic since one subtest had a heading that contained the term "calculation." In addition, almost all of the items in that subtest concerned arithmetic. The situation was different between 1986 and 1995 as all subtests contained a mixture of items corresponding to the syllabus topics arithmetic and algebra. However, here it is important to note that the items that are categorised as algebra in my analysis also concerned arithmetic. This is related to the fact that the algebra items involved the four rules of arithmetic. Thus, the possibilities to evaluate the students' knowledge in arithmetic were still good.

The framing of algebra, on the other hand, was weak as the test results provided less clear information of the students' achievements in algebra. Throughout the period, there was no subtest dedicated to algebra. In each subtest that contained algebra, algebra items were always mixed with arithmetic items. Moreover, there were always quite few algebra items in absolute numbers. Finally, several algebra items involved geometry or applications, which make evaluation more difficult because students might fail for reasons other than incomplete skills in algebra. The same condition could be said for arithmetic, but this circumstance was more crucial in algebra since there were much fewer items.

\section{Classification and framing in the textbooks}

For the textbooks for years 4-6, the overall conclusion is that arithmetic had a strong classification and algebra had a weak classification. A clear majority of the tables

84 See Table 5 in Appendix B.

85 See Table 4 in Appendix B.

86 See Table 4 in Appendix B. 
of content and the headings of chapters and subchapters included words related to arithmetic, for instance addition, subtraction, numbers, fractions, and per cent. Only a few included words related to algebra, for instance "We seek the unknown," 87 "Co-ordinate system," 88 and "Elementary introduction of the function concept." 89 However, the classification of algebra varied: for example Undvall used expressions in the headings that were related to both equations and functions and Rockström and Skoogh et al. only used expressions related to functions. Differences were also evident over time. In Undvall's two earlier series, expressions related to equations (once) appeared only in the subheadings in year 4; in the third and last series, such an expression was used as the heading for a whole chapter. In Skoogh et al.s series, the opposite change occurred: the heading that included the expression "function" was only used in the first series (i.e., the heading was not used in the second series). Thus, in some textbooks algebra received a comparatively stronger classification, which also appeared earlier in some. In general, however, the classification of arithmetic was much stronger since the headings included words that were clearly related to that topic.

In the textbooks intended for years 4-6, the framing of arithmetic and algebra was also different. Despite the fact that many chapters had heading that did not indicate content related to algebra, algebra exercises did appear in those chapters. For example, the symbol $x$ and simple equations of the type $a^{*} x=b$ or $x^{*} a=b$ were included in all books in year 4, except for Skoogh et al.'s last series, where it was introduced in year 5. In fact, Rockström was the most ambitious when it came to equations: by year 5 , she included two equations with the symbol $x$ on both sides of the equal sign and problems with balance scales that in theory are systems of two linear equations with two unknowns. ${ }^{90}$ Skoogh et al.'s series (years 5 and 6) and Rockström (year 4) also provided exercises about patterns where students were supposed to continue a given series of numbers or geometric pictures; for example, the pictures could represent matches arranged in geometric forms. These patterns were not mentioned in the 1980 syllabus; however, in the Swedish discourse on school mathematics in the 1990s, patterns were associated with algebra. ${ }^{91}$

The chapters on geometry also addressed algebra in connection to the area formulas for rectangles and triangles with the volume formula for a rectangular block. The formula for the rectangle and the associated exercises were introduced by Undvall (all series) and Rockström (year 5). Skoog et al., in the first series in year 5, addressed the area of the rectangle and how it can be calculated, but they did not give an explicit formula. In Skoogh et al.s last series, the area of rectangles and triangles

87 “Vi söker det okända," Lennart Undvall (ed.), Alma Grundbok A (Stockholm: Almqvist \& Wiksell, 1994), 71. This chapter was introduced in year 4.

88 “Koordinatsystem," Lennart Undvall (ed.), Matematikboken 5 (Stockholm: Esselte studium, 1989), 237. Birgitta Rockström, Matematik för mellanstadiet 6A. Grundbok. (Båstad: Kreativa, 1994), 93. Undvall introduced this chapter in the second semester of year 5, Rockström in the first semester of year 6 .

89 Lennart Skoogh et al., Räkneresan E (Stockholm: Almqvist \& Wiksell, 1993), 42. This chapter was introduced in the first semester in year 6.

90 Birgitta Rockström, Matematik för mellanstadiet 5B. Grundbok. (Båstad: Kreativa, 1993), 35, 37, 70.

91 See for example Christer Bergsten, et al., Algebra för alla (Mölndal: Institutionen för ämnesdidaktik, Göteborgs universitet, 1997), 79-104. 
were treated in both year 5 and year 6 and also without formulas; much emphasis was put on making estimations by means of drawings and grids. The formula for the volume of rectangular block was introduced in year 6 by all authors, except for Skoogh et al.'s who excluded this in their last series. Notably, the formulas for area and circumferences of a circle were introduced only by Rockström and then in year 6 . Algebra also appeared in connection to angles and triangles, but then only in Undvall and Rockström and in year 6. The most common exercise in this respect was based on the fact that the sum of angles of any triangle always equals 180 degrees. Students were to use two known angles to calculate the third angle. The symbol $x$ was also used to indicate the unknown angle in the diagram.

There are some differences when exercises related to algebra were introduced and to what extent. The general picture is that Undvall and Rockström introduced this type of exercise earlier than Skoogh et al. Moreover, Undvall and Rockström included more exercises related to algebra. Here we need to recall that arithmetic was the dominating topic in years 4-6, so in comparison to the total amount of exercises of all sorts, the number of algebra exercises was relatively few in all textbooks.

Another difference between the authors is the level of formalism. Undvall and Rockström more frequently used formulas and letter symbols for unknowns than Skoogh et al. Moreover, Skoogh et al. did not use area formulas for rectangles and triangles in the later series. The introduction of the coordinate system was also done differently. Undvall and Rockström had a more pure or formal approach as they explicitly introduced the notions of coordinates and axes without applications. Skoogh et al., on the other hand, introduced the coordinate system in connection to statistics and it appeared as one type of chart.

If we consider changes over time, there is no general trend with respect to algebra. Undvall's series changed very little. In two Skoogh et al.s series, the general tendency was to postpone parts related to algebra or exclude some parts completely. Rockström, on the other hand, went in the other direction: she introduced more complex equations already in year 5 , she introduced patterns already in year 4 , and she was the only one to introduce the formulas for the area and circumference of the circle, this in year 6.

The exercises in arithmetic have not been analysed as thoroughly, but they clearly constituted a great majority in all books in all years. So in comparison to algebra, the framing of arithmetic can be considered to have been stronger.

A major difference between the series concerns the balance between pure and applied exercises, both in arithmetic and all other topics. To a much greater degree, Skoogh et al. included applied exercises.

In summary, the overall conclusion about framing in the textbooks intended for years 4-6 is that arithmetic had a strong framing and algebra had a weak framing. The argument for strong framing of arithmetic is that it was clear when and to what extent the textbooks addressed arithmetic: several chapters were designated as arithmetic and contained many exercises in arithmetic. The situation was quite different in algebra: few chapters, in some books none, were dedicated to algebra. Moreover, the relatively few exercises related to algebra often appeared in chapters dedicated to other topics. There were, however, differences with respect to the framing of algebra. In Undvall's and Rockströms' series, the framing was stronger as algebra was treated more explicitly and extensively. In Skoogh et al.s series, the framing was weak. 
For the textbook series intended for years 7-9, the general conclusion is that the classification of arithmetic as well as algebra was strong. By and large, each book series for each year contained chapters dedicated to arithmetic and algebra as well as geometry and statistics. In chapters related to arithmetic, the headings contained expressions such as "Percentage" and "Negative numbers." The heading of the algebra chapters contained expressions such as "Algebra," "Equations," "Functions," and "Variables." However, in Skoogh et al., the first chapter explicitly dedicated to algebra appeared in Book D-that is, the book intended for the second semester of year 8. Thus, a chapter dedicated to algebra was introduced a year later in Skoogh et al.'s series than in the other series. Skoogh et al. also used informal headings such as "Count with us" and "Number speaks" for arithmetic and "The ABC of mathematics" for algebra. Skoog et al. also included thematic chapters where the students were supposed to solve real world problems. The heading for the first one in year 7 was "Now we are going to have fun" and the content concerned a trip to an amusement park. Apart from thematic chapters, there was also a more general theme occurring throughout the series that involved four students. On several instances, the exercises concerned different situations this group of students got involved in. For example, the students had a pop band that was on a tour, which gave rise to a number of mathematical problems.

As regards to the framing, the overall picture is that the framing of all topics (arithmetic, algebra, geometry, and statistics) was strong, not just arithmetic as in years 4-6. That is, each topic had chapters explicitly dedicated to these topics, a great majority of the exercises and explanations in these chapters concerned the designated topic, and the number of pages of these chapters was very seldom below 10 per cent per topic of the total amount of pages in each book. ${ }^{92}$ I denote these types of pages and chapters "topic dedicated pages and chapters." However, some authors did exclude some topics for some years.

If we look more closely at the framing of arithmetic and algebra - when the topics were introduced and to what extent - the overall trend was that the total share of topic dedicated pages and chapters in the series was stable for arithmetic and slightly decreased for algebra. ${ }^{93}$ The share of dedicated pages in arithmetic varied between 31 and 35 per cent of the total number of pages; for algebra, the share was between 25 and 29 per cent before 1989 and between 22 and 24 per cent after 1989. ${ }^{94}$ The exception was Skoogh et al.s series: the shares of dedicated pages and chapters in arithmetic and algebra were 47 and 20 per cent, respectively, of the total number of pages. The general decrease in chapters and pages dedicated to algebra was, however, not evenly distributed over the school years. In year 7, the decrease was considerably greater and in year 9 it even increased a bit. Notably, in the series by Skoogh et al there were no dedicated chapters to algebra at all in year 7, even though algebra was treated in other chapters. Another general trend in the framing of arithmetic and algebra is that the variation increased around 1990. The main contributor to this variation was Skoogh et al's series.

So far, only the chapters and pages dedicated to certain topics have been discus-

92 See Appendix D.

93 See Appendix D.

94 Appendix D. 
sed. However, in some chapters other topics were integrated into these chapters. This integration was also the case with algebra. All the authors did so, but in particular Mårtensson et al. included a lot of algebra in the chapters dedicated to arithmetic and geometry and this was already done in year 7 . This difference is another example of how the design of the textbooks could vary.

\section{Conclusions}

One aim of this article is to describe the design of the arithmetic and algebra curricula (1-9) between 1980 and 1995. The analysis presented in the previous sections show that classification of both topics was strong and they were well insulated from each other. That is, the two topics were explicitly described and labelled in the syllabus and the commentary material. The two topics were also insulated from each other in the sense that few overlaps between the topics were explicitly described. This insulation was further strengthened by a great emphasis on everyday problems, which was expressed both in the syllabus and the commentary material: arithmetic was very much considered a part of that area, whereas algebra was not.

The framing of arithmetic was strong and the framing of algebra was weak, the latter in particular in years 1-6. Strong framing in this study means that there were more detailed and explicit descriptions about organisation and pacing. Organisation concerns the sequence of different parts of the school subject during the teaching processes. Pacing is about speed, time, and extensiveness of what the students are supposed to learn. The characterisation of strong framing of arithmetic and weak framing of algebra applies to the syllabus and the commentary material in years 1-9. Typically, the descriptions about organisation and pacing were to a great degree based on purely mathematical language. Strong framing of arithmetic was also achieved in the national exam in year 9 and in diagnostic tests for years 3-4, 6-7, and $8-9$, which were issued by the central school authorities. The national exams contained items in arithmetic and algebra, but only arithmetic was an explicit topic and there were more items in arithmetic. The diagnostic tests contained items in arithmetic, but none in algebra. Thus, national exams and diagnostic tests offered clearer guidelines in arithmetic than in algebra about what concepts to cover, to what extent to cover these, and when the students were supposed to learn these concepts. Another aspect of stronger framing of arithmetic concerns the purpose of the topic. The 1980 syllabus and the commentary material provided a clear focus on problem solving in an everyday context. In particular, the role of arithmetic in that context was thoroughly described in the curriculum.

The second aim of this article is to examine whether differences in the design of the curricula of arithmetic and algebra can explain differences in SIMS1980 and TIMSS1995 results in those two topics. The fact that strong framing of arithmetic, as it is defined and analysed in this study, can be associated with much improved results in arithmetic in TIMSS and that weak framing of algebra can be associated with no improved results in algebra in TIMSS suggests there was a causal relation between the level of framing and TIMSS results: strong framing gave improved results, whereas weak framing gave a neutral result. The fact that classification of arithmetic as well as algebra was strong suggests that strong classification alone was not sufficient to improve the results. Here we should recall that proportionality was a separate category in TIMSS whereas it was part of the arithmetic in SIMS. In TIMSS, the results 
in this category were low, at the same level as algebra. Important to note, both classification and framing of proportionality were weak in the curriculum. This confirms the above reasoning about levels of framing and student results.

The conclusion about a causal relation between the level of framing in the curriculum and TIMSS results is further supported by the analysis of popular textbooks. The textbooks mirrored the framing of arithmetic and algebra in the syllabus and the commentary material. Framing in the textbooks was strong with respect to arithmetic for the years 4-6 and 7-9, a bit weaker for algebra for the years 7-9, and much weaker for algebra for the years 4-6. The classification of algebra in the textbooks was a bit different: in years 4-6, classification was weak. However, arithmetic in years 4-6 and 7-9 and algebra in years 7-9 had strong classification, just as in the curriculum. If the levels of classification and framing, in particular the latter, had been much different in the textbooks than in the curriculum, my conclusion about a causal relation would have been severely undermined.

The analysis of popular textbooks also supports the conclusion about causality and the importance of framing in the curriculum since the textbook producers and teachers seem to have behaved in accordance with the theory of classification and framing. Recall that weak framing in the curriculum also is a matter of giving less specific directives-more freedom-to textbook producers and the teachers, the consumers of textbooks. In the textbooks there was greater variety in the framing of algebra than in the framing of arithmetic, especially for years 4-6. This effect appears to have been protracted in the sense that the variety was greater in the end of the period than in the beginning of the period. In some of the later textbooks (4-6), some types of exercises related to algebra were either postponed to later years in the span 4-6 or removed completely. However, the opposite trend is also evident: in one of the series some types of exercises appeared in earlier years and completely new types of exercises were added. In the textbooks for 7-9, the variation concerned the number of chapters and pages explicitly dedicated to algebra. The variation was greater in the end than in the beginning of the period; in the early 1990s, the time for introduction of more dedicated and comprehensive chapters on algebra could differ by up to two semesters. In most series, this introduction was done in the second semester of year 7, but in one series it was done in the second semester of year 8. For the years 7-9, there was also a general trend over time to reduce the number of pages and chapters dedicated to algebra, especially in year 7. Similar changes and variations did not occur for arithmetic sections in the textbooks.

My conclusion about causality and the importance of framing develops the explanation of the low result in algebra in 1995 presented in the official Swedish TIMSS report. In this report, it is argued, briefly, that the low result was due to algebra being a topic of low priority and treated late in the schools. ${ }^{95} \mathrm{~A}$ weakness of this explanation is its indistinctiveness. The curriculum was vague about what and how much algebra should be covered each year, which has been shown above. Thus, the curriculum alone said little about when and how much algebra was taught in years 4-6 and 7-9. We have also seen that algebra was treated quite differently in popular textbooks, both in years 4-6 and 7-9, especially in the early 1990s. My results suggest that late treatment of algebra was not a general phenomenon; the teaching in years 7-9 probably

95 Skolverket (1996), 48, 85. 
varied quite a bit with respect to when a more comprehensive treatment of the topic was introduced in the textbooks. Thus, the low result in algebra could have been caused by those teachers (7-9) choosing textbooks where chapters dedicated to algebra appeared very close to or after the TIMSS test.

As discussed in the section of theory and method, my conclusions about a causal relation between levels of framing in the curriculum and student results could be further corroborated with other sources that explain what happened between the introduction of a new curriculum in 1980 and improved results in 1995. The presented textbook analysis is a step in that direction, but other sources could be considered such as material from teacher's in-service training and teacher education. Another possibility is to interview teachers who were active in this period.

In relation to previous historical research on ideological governance and school subjects in Sweden, my findings concerning different types of curriculum designs and their effect on student results are original. This issue is not well researched. ${ }^{96}$ Moreover, there are reasons for further studies regarding this issue. My findings raise a critical question about the change in governing policy that took place in Sweden between 1975 and 2000: Was it a good policy for governance of school subjects? We know that a general policy of decentralisation was emphasised in several official investigations about the school system in the late 1970s and early 1980s. A less regulating national curriculum would be in line with that ambition, which to some extent did happen in the 1980s; the 1980 curriculum prescribed contents of school subjects by year spans-1-3, 4-6, and 7-9-rather than by years. This is an example of weaker framing and more decisions about organisation and pacing were left to schools and teachers. However, my results about strong framing of arithmetic in the 1980 curriculum in comparison to the framing of algebra come across as a deviation in that context. This confirms Lindensjö and Lundgren's remark about "interesting" differences between the prescribed principles for designing the 1980 curriculum and the produced curriculum. ${ }^{97}$ The present study shows what those deviations were in school mathematics and that they seem to have had positive effects on student results. These results hint that a curriculum design less aligned with the logic of decentralisation could produce better student results. We can compare this with how Gustavsson and Blömeke conclude that the good results in international tests between 1964 and 1995 were due to the combined effect of different measures taken to improve schools. ${ }^{98}$ My results support a view that those measures were not related to a curriculum design closely adhering to the vision of decentralising the school system. However, just like Gustavsson and Blömeke, I cannot sort out different measures as more important than other. It might be that certain decisions about school economy, a general pedagogical trend, or even decentralisation of other parts of the school system were necessary conditions for improving the results in arithmetic. Nonetheless, my study indicates that stronger framing of school subjects in the curriculum was one of the necessary conditions for success, at least in school mathematics.

96 Cf. section on previous research in this article.

97 Lindensjö and Lundgren (2014), 83-84.

98 Gustafsson and Blömeke (2018), 402. 


\section{Acknowledgements}

The research has been funded by the Swedish Research Council. The use of SIMS and TIMSS items has been approved by the International Association for the Evaluation of Educational Achievement (IEA). I sincerely thank both organisations. I also thank the two anonymous reviewers for their valuable comments and suggestions. 


\section{References}

\section{Sources}

Syllabus, commentary material and diagnostic tests

Skolöverstyrelsen. Läroplan för grundskolan. Allmän del: Mål och riktlinjer, kursplaner, timplaner. Stockholm: LiberLäromedel/Utbildningsförlaget, 1980.

Skolöverstyrelsen. Läroplan för grundskolan. Kommentarmaterial. Att räkna: en grundläggande färdighet. Stockholm: LiberLäromedel/Utbildningsförlaget, 1982. Skolöverstyrelsen. SÖ:s diagnostiska uppgifter i matematik. Metodisk handledning. (1. uppl.).Stockholm: LiberUtbildningsförlaget, 1983.

Skolöverstyrelsen. SÖ:s diagnostiska uppgifter i matematik. Lärarhandledning; Översiktsdiagnoser med facit [åk] 3-4, [åk] 6-7, [åk] 8-9; Facit till elevhäfte åk 9. Stockholm: LiberUtbildningsförlaget, 1988.

National tests (Standardprov) year 9, 1980-1984

Arkiv: Skolöverstyrelsen

54 Avdelningen för lärarutbildning/lärarfortbildning och pedagogiskt utvecklingsarbete (L-avd) 1964-1984.

04 Sektionen för prov och utvärdering, L 4:1, L 4:3 samt programmet prov 1982-1984. F I bie Standardprov i matematik, volym 9, 1980-1984.

National tests (Standardprov) year 9, 1984-1990

Arkiv: Skolöverstyrelsen

68 Avdelningen för planering och samordning, PS, samt juridisk enhet, 1982-1991.

02 Övergripande planeringssekreteriat 1982-1991.

B 2 A Standardprov, grundskolan, volym 2, 1984-1990.

National tests (Standardprov) year 9, 1990-1995

Lärarhögskolan i Stockholm. Institutionen för undervisningsprocesser, kommunikation och lärande. PRIM-gruppen, PRIM-gruppens matematikuppgifter för årskurs 9: Använda vid prov och utvärderingar på nationell nivå 1987-1999. Stockholm: Lärarhögskolan, 1999.

Textbooks, years 4-6

Rockström, Birgitta. Matematik för mellanstadiet 4A. Grundbok. Båstad: Kreativa, 1993. Rockström, Birgitta. Matematik för mellanstadiet 4B. Grundbok. Båstad: Kreativa, 1991. Rockström, Birgitta. Matematik för mellanstadiet 5A. Grundbok. Båstad: Kreativa, 1993. Rockström, Birgitta. Matematik för mellanstadiet 5B. Grundbok. Båstad: Kreativa, 1993. Rockström, Birgitta. Matematik för mellanstadiet 6A. Grundbok. Båstad: Kreativa, 1994. Rockström, Birgitta. Matematik för mellanstadiet 6B. Grundbok. Båstad: Kreativa, 1996. Skoogh, Lennart, Bengt Nilsson, and Håkan Johansson. Räkneresan A. Stockholm: Almqvist \&Wiksell, 1986.

Skoogh, Lennart, Bengt Nilsson, and Håkan Johansson. Räkneresan B. Stockholm: Almqvist \& Wiksell, 1987.

Skoogh, Lennart, Bengt Nilsson, and Håkan Johansson. Räkneresan C. Stockholm: Almqvist \&Wiksell, 1990. 
Skoogh, Lennart, Bengt Nilsson, and Håkan Johansson. Räkneresan D. Stockholm: Almqvist \& Wiksell, 1991.

Skoogh, Lennart, Bengt Nilsson, and Håkan Johansson. Räkneresan E. Stockholm: Almqvist \& Wiksell, 1993.

Skoogh, Lennart, Bengt Nilsson, and Håkan Johansson. Räkneresan F. Stockholm: Almqvist \& Wiksell, 1992.

Skoogh, Lennart, Bengt Nilsson, and Håkan Johansson. Räkneresan X2001. Stockholm: Almqvist \& Wiksell, 1995.

Skoogh, Lennart, Bengt Nilsson, and Håkan Johansson. Räkneresan X2002. Stockholm: Almqvist \& Wiksell, 1996.

Skoogh, Lennart, Bengt Nilsson, and Håkan Johansson. Räkneresan X2003. Stockholm: Almqvist \& Wiksell, 1998.

Undvall, Lennart (ed.). Matematikboken 4. Stockholm: Esselte studium, 1979.

Undvall, Lennart (ed.). Matematikboken 5. Stockholm: Esselte studium, 1982.

Undvall, Lennart (ed.). Matematikboken 6. Stockholm: Esselte studium, 1981.

Undvall, Lennart (ed.). Matematikboken 4, 3 ed. Stockholm: Esselte studium, 1987.

Undvall, Lennart (ed.). Matematikboken 5, 3 ed. Stockholm: Esselte studium, 1989.

Undvall, Lennart (ed.). Matematikboken 6, 3 ed. Stockholm: Esselte studium, 1987.

Undvall, Lennart (ed.). Alma Grundbok A. Stockholm: Almqvist \& Wiksell, 1994.

Undvall, Lennart (ed.). Alma Grundbok B. Stockholm: Almqvist \& Wiksell, 1994.

Undvall, Lennart (ed.). Alma Grundbok C. Stockholm: Almqvist \& Wiksell, 1995.

Textbooks, year 7-9

Alvin, Inga and Bengt Anderberg. Sjuans matematik. 1 s, Min mattebok. Gävle: Skolförlaget, 1984 .

Alvin, Inga and Bengt Anderberg. Sjuans matematik. 2 s, Min mattebok. Gävle: Skolförlaget, 1986.

Alvin, Inga and Bengt Anderberg. Åttans matematik. 1 s, Min mattebok. Gävle: Skolförlaget, 1984 .

Alvin, Inga and Bengt Anderberg. Åttans matematik. 2 s, Min mattebok. Gävle: Skolförlaget, 1984.

Alvin, Inga and Bengt Anderberg. Nians matematik. 1 s, Min mattebok. Gävle: Skolförlaget, 1986.

Alvin, Inga and Bengt Anderberg. Nians matematik. 2 s, Min mattebok. Gävle: Skolförlaget, 1984.

Mårtensson, Gert and Leif Svensson. Beta: Högstadiets matematik. Åk 7, Särskild kurs, Bok 1. Malmö: LiberLäromedel, 1982.

Mårtensson, Gert and Leif Svensson. Beta: Högstadiets matematik. Åk 7, Särskild kurs, Bok 2. Malmö: LiberLäromedel, 1982.

Mårtensson, Gert and Leif Svensson. Beta: Högstadiets matematik. Åk 8, Särskild kurs, Bok 1. Malmö: LiberLäromedel, 1983.

Mårtensson, Gert and Leif Svensson. Beta: Högstadiets matematik. Åk 8, Särskild kurs, Bok 2. Malmö: LiberLäromedel, 1983.

Mårtensson, Gert and Leif Svensson. Beta: Högstadiets matematik. Åk 9, Särskild kurs. Malmö: LiberLäromedel, 1984.

Mårtensson, Gert and Leif Svensson. Beta: Högstadiets matematik. 7, [Röd]: [särskild kurs]. Malmö: Liber, 1989. 
Mårtensson, Gert and Leif Svensson. Beta: Högstadiets matematik. 8, [Röd]: [särskild kurs]. Malmö: Liber, 1989.

Mårtensson, Gert and Leif Svensson. Beta: Högstadiets matematik. 9, [Röd]: [särskild kurs]. Malmö: Liber, 1989.

Skoogh, Lennart (ed.). Möte med matte: [Matematik för högstadiet]. A. Solna: Esselte studium, 1990.

Skoogh, Lennart (ed.). Möte med matte: [Matematik för högstadiet]. B. Solna: Esselte studium, 1990.

Skoogh, Lennart (ed.). Möte med matte: [Matematik för högstadiet]. C. Solna: Esselte studium, 1991.

Skoogh, Lennart (ed.). Möte med matte: [Matematik för högstadiet]. D. Solna: Esselte studium, 1990.

Skoogh, Lennart (ed.). Möte med matte: [Matematik för högstadiet]. E. Solna: Esselte studium, 1994.

Skoogh, Lennart (ed.). Möte med matte: [Matematik för högstadiet]. F. Solna: Esselte studium, 1991.

Undvall, Lennart, Karl-Gerhard Olofsson and Svante Forsberg. Matematikboken för högstadiet. Sk 7, [Lärobok]. Stockholm: Esselte studium, 1979.

Undvall, Lennart, Karl-Gerhard Olofsson and Svante Forsberg. Matematikboken för högstadiet. Sk 8, [Lärobok]. Stockholm: Esselte studium, 1984.

Undvall, Lennart, Karl-Gerhard Olofsson and Svante Forsberg. Matematikboken för högstadiet. Sk 9, [Lärobok]. Stockholm: Esselte studium, 1986.

Undvall, Lennart (ed.), Matematikboken för högstadiet. 7S. Solna: Esselte studium, 1985.

Undvall, Lennart (ed.), Matematikboken för högstadiet. 8S. Solna: Esselte studium, 1991.

Undvall, Lennart (ed.), Matematikboken för högstadiet. 9S. Solna: Esselte studium, 1990.

Undvall, Lennart, Karl-Gerhard Olofsson and Svante Forsberg. Matematikboken för högstadiet: $A B C$. [Åk] 7. Solna: Almqvist \& Wiksell läromedel, 1994.

Undvall, Lennart, Karl-Gerhard Olofsson and Svante Forsberg. Matematikboken för högstadiet: ABC. [Åk] 8. Solna: Almqvist \& Wiksell läromedel, 1991.

Undvall, Lennart, Karl-Gerhard Olofsson and Svante Forsberg. Matematikboken för högstadiet: ABC. [Åk] 9. Solna: Almqvist \& Wiksell läromedel, 1993.

\section{Literature}

Alvén, Fredrik. Tänka rätt och tycka lämpligt: Historieämnet i skärningspunkten mellan att fostra kulturbärare och förbereda kulturbyggare [PhD diss.]. Malmö: Malmö högskola, 2017.

Beaton, Albert E., Ina V.S. Mullis, Michael O. Martin, Eugino J.Gonzalez, Dana L. Kelly, and Teresa A. Smith. Mathematics Achievement in the Middle School Years. IEA's Third International Mathematics and Science Study (TIMSS). Chestnut Hill: TIMSS International Study Center, Boston College, 1996.

Bergsten, Christer, Johan Häggström, and Lisbeth Lindberg. Algebra för alla. Mölndal: Institutionen för ämnesdidaktik, Göteborgs universitet, 1997.

Bernstein, Basil. Class, Codes and Control, vol. 1: Theoretical Studies Towards a Sociology of Language, 2. rev. ed. London: Routledge, 1974. 
Börjesson, Mattias. Från likvärdighet till marknad: En studie av offentligt och privat inflytande över skolans styrning i svensk utbildningspolitik 1969-1999 [PhD diss.] Örebro: Örebro universitet, 2016.

Bronäs, Agneta. Demokratins ansikte: En jämförande studie av demokratibilder i tyska och svenska samhällskunskapsböcker för gymnasiet [PhD diss.]. Stockholm: Stockholms universitet, 2000.

Englund, Tomas. Samhällsorientering och medborgarfostran i svensk skola under 1900-talet. Uppsala: Uppsala universitet, Pedagogiska institutionen, 1986.

Forsberg, Eva, Elisabet Nihlfors, Daniel Pettersson, and Pia Skott. "Curriculum Code, Arena, and Context: Curriculum and Leadership Research in Sweden." Leadership and Policy in Schools 16, no. 2 (2017), 357-82.

Gustafsson, Jörgen. Historielärobokens föreställningar: Påbjuden identifikation och genreförändring i den obligatoriska skolan 1870-2000 [PhD diss.]. Uppsala: Uppsala universitet, 2017.

Gustafsson, Jan-Eric and Sigrid Blömeke. "Development of School Achievement in the Nordic Countries During Half a Century." Scandinavian Journal of Educational Research 62, no. 3 (2018), 386-406.

Hultén, Magnus. Naturens kanon: Formering och förändring av innehållet $i$ folkskolans och grundskolans naturvetenskap 1842-2007 [PhD diss.]. Stockholm: Stockholms universitet, 2008.

Johnsson Harrie, Anna. Staten och läromedlen: En studie av den svenska statliga förhandsgranskningen av läromedel 1938-1991 [PhD diss.]. Linköping: Linköpings universitet, Institutionen för beteendevetenskap och lärande, 2009.

Lindensjö, Bo and Ulf P. Lundgren. Utbildningsreformer och politisk styrning. Stockholm: Liber, 2014.

Ljung, Bengt-Olov, Bo Rosén, and Edor Oscarsson. Översiktsdiagnos i matematik inför skolstarten på treåriga gymnasielinjer. Stockholm: Högskolan i lärarutbildning i Stockholm, Institutionen för pedagogik, 1991.

Lundahl, Christian. Viljan att veta vad andra vet: Kunskapsbedömning i tidigmodern, modern och senmodern skola [PhD diss.]. Uppsala: Uppsala universitet, 2006.

Läromedelsöversynen. Skolböcker: Rapport från Läromedelsöversynen 2. 400 klasser i grundskolan. Stockholm: Allmänna förl., 1988.

Nordmark, Jonas. Med en framtida demokrat som adressat: Föreställningar om framtid i svenska samhällskunskapsböcker 1992-2010 [PhD diss.]. Västerås: Mälardalens högskola, 2015.

Oftedal Telhaug, Alfred, Odd Asbjørn Mediås, and Petter Aasen. “The Nordic Model in Education: Education as part of the political system in the last 50 years." Scandinavian Journal of Education 50, no. 3 (2006), 245-83.

Prytz, Johan. The Construction of a Database Regarding Swedish Historical Textbooks in Mathematics (grades 1-9), 1900-2015: A Technical Description. Uppsala: Uppsala universitet, 2016.

Prytz, Johan. "The New Math and School Governance: An Explanation of the Decline of the New Math in Sweden." In Researching the History of Mathematics Education. ICME-13 Monographs, edited by Fulvia Furinghetti and Alexander Karp, 189-216. Cham: Springer, 2018.

Prytz, Johan and Johanna Ringarp. "Local Versus National History of Education. The Case of Swedish School Governance, 1950-1990.” In Transnational Perspectives 
on Curriculum History, edited by Gary McCulloch, Ivor Goodson and Mariano González-Delgado. London: Routledge, 2019.

Pelgrum, W. J., Th. Eggen, and Tj.Plomp. The Implemented and Attained Mathematics Curriculum: A Comparison of Eighteen Countries. Second International Mathematics Study. Contractor's Report. Enschede: Twente University of Technology, 1986.

Richardson, Gunnar. Svensk utbildningshistoria: Skola och samhälle förr och nu, 8. rev. ed. Lund: Studentlitteratur, 2010.

Skolverket. Den nationella utvärderingen av grundskolan våren 1992: Matematik, Åk 9, Huvudrapport. Stockholm: Statens skolverk, 1993.

Skolverket. TIMSS: Svenska 13-åringars kunskaper i matematik och naturvetenskap $i$ ett internationellt perspektiv. Stockholm: Statens skolverk, 1996.

Skolverket. Vad påverkar resultaten i svensk grundskola? Kunskapsöversikt om betydelsen av olika faktorer: Sammanfattande analys. Stockholm: Skolverket, 2009.

Skott, Pia. "Utbildningspolitik och läroplanshistoria." In Utbildningshistoria: En introduktion, edited by Esbjörn Larsson and Johannes Westberg, 325-340. Lund: Studentlitteratur, 2011.

Third International Mathematics and Science Study (TIMSS). TIMSS Mathematics Items: Released Set for Population 2 (seventh and eighth grades ): IEA's Third International Mathematics and Science Study. IEA TIMSS, 1997.

TIMSS. "IEA's Repeat of the Third International Mathematics and Science Study at the Eighth Grade. TIMSS Mathematics Items: Released Set for Eight Grade." Boston College. https://timssandpirls.bc.edu/timss1999i/pdf/t99math_items. pdf (accessed October 5, 2018).

TIMSS 2003 Assessment. "TIMSS2003 Mathematics Items. Released Set Eight Grade.” Boston College. https://timssandpirls.bc.edu/PDF/T03_RELEASED M8.pdf (accessed October 5, 2018).

Travers, Kenneth J. and Ian Westbury. The IEA Study of Mathematics. 1: Analysis of Mathematics Curricula, Supplement. New York: International Association for the Evaluation of Educational Achievement, 1989.

Utbildningsdepartementet. Läroplaner för det obligatoriska skolväsendet och de frivilliga skolformerna: Lpo 94: Lpf 94. Stockholm: Utbildningsdep., 1994.

Åström Elmersjö, Henrik. En av staten godkänd historia: Förhandsgranskning av svenska läromedel och omförhandlingen av historieämnet 1938-1991. Lund: Nordic Academic Press, 2017.

Östman, Leif. Socialisation och mening: No-utbildning som politiskt och miljömoraliskt problem [PhD diss.]. Uppsala: Uppsala universitet, 1995. 


\section{Appendix A. Arithmetic and Algebra in SIMS1980, TIMSS1995, and the 1980 curriculum}

To a large degree, the sections on "Arithmetic" in SIMS1980 and "Fractions and Number Sense" (FNS) in TIMSS1995 concern the same areas of knowledge. The same is true for the section denoted "Algebra." Moreover, the sections on "Arithmetic" and "FNS" and "Algebra" in SIMS1980 and TIMSS1995 cover, to a large degree, the same area of knowledge that I have identified as arithmetic and algebra in the Swedish1980 curriculum.

These claims are based on a comparison between subject matter descriptions concerning arithmetic and algebra in the 1980 curriculum and the items in SIMS and TIMSS. I have applied a procedure similar to the one described in Appendix C. The critical difference is that the items I categorise as "Arithmetic," "Percentage," and "Proportionality" are considered "Arithmetic" in the analysis of the SIMS items and the items I categorise as "Arithmetic" and "Percentage" are considered "FNS" in the analysis of the TIMSS items while "Proportionality" is "Proportionality." The reason for this is that proportionality was a specific topic in TIMSS, but not in SIMS. In SIMS, proportionality was a part of the category "Arithmetic" Thus, the categories of "Arithmetic" in Table 3 (Appendix A) are wider than the category of "Arithmetic" in Table 4 (Appendix B). The results of the analysis are accounted for in Table 3.

Table 3 should be understood in the following way.

- The categories "Arithmetic/FNS," "Algebra," and "Proportionality" are the categories used in SIMS and TIMSS. The items in each column are the items categorised as "Arithmetic/FNS," "Algebra," or "Proportionality" by IEA.

- Items not highlighted are items that I have categorised as arithmetic or algebra according to the Swedish 1980 curriculum and where there is no conflict with the categorisations of SIMS and TIMSS.

- Items highlighted in light grey are items where SIMS1980 and the 1980 curriculum do not agree. The SIMS algebra items should be 1980 curriculum arithmetic items and SIMS arithmetic items should be 1980 curriculum algebra items. However, this does not affect the overall SIMS results in arithmetic and algebra since the average solution frequencies of the two groups of items are almost equal; the difference is about 1 percentage unit. The solution frequencies are collected from a report by Pelgrum et al..$^{99}$

- $\quad$ The item highlighted in medium grey are an item where TIMSS1995 and the 1980 curriculum do not agree. The TIMSS arithmetic item should be a 1980 curriculum algebra item. This in only one item so the effect on overall results is very small.

- $\quad$ Items highlighted in dark grey are most likely the items that belonged to the category of "Proportionality." These items were released in connection to the release of some of the items from TIMSS1999 and TIMSS2003. In these tests, the category "Proportionality" was removed and the reused items from this category were re-categorised. I believe that these items belonged to the category "Proportionality" in 1995 since these are the items that involve reasoning about proportionality or proportions.

99 Pelgrum et al. (1986), 99-107. 


\section{Johan Prytz}

Table 3. Arithmetic and Algebra in SIMS1980, TIMSS1995, and the 1980 curriculum

\begin{tabular}{|c|c|c|c|c|c|c|}
\hline \multicolumn{3}{|l|}{ SIMS1980 } & \multicolumn{4}{|c|}{ TIMSS1995 } \\
\hline \multicolumn{2}{|l|}{ Arithmetic } & \multirow{2}{*}{$\begin{array}{l}\text { Algebra } \\
\text { Item } n r\end{array}$} & \multicolumn{2}{|c|}{ Fractions and Number Sense } & \multirow{2}{*}{$\begin{array}{l}\text { Algebra } \\
\text { Item } n r\end{array}$} & \multirow{2}{*}{$\begin{array}{l}\text { Proportionality } \\
\text { Item } \mathrm{nr}\end{array}$} \\
\hline Item $n r$ & Item $n r$ & & Item $n r$ & Item $n r$ & & \\
\hline $4(076)$ & $85(139)$ & $3(151)$ & $\mathrm{I} 2$ & $\mathrm{R} 13$ & I1 & L14 \\
\hline $12(079)$ & $90(137)$ & $13(017)$ & I5 & R6 & I4 & M6 \\
\hline $15(045)$ & $91(010)$ & $16(012)$ & I6 & R7 & $\mathrm{J} 18$ & Q5 \\
\hline $20(109)$ & $95(080)$ & $18(086)$ & I7 & U1 & K4 & R14 \\
\hline $26(005)$ & $98(143)$ & $25(013)^{\prime}$ & $\mathrm{J} 12$ & $\mathrm{~V} 1$ & L11 & $\mathrm{T} 2$ \\
\hline $28(075)$ & $108(145)$ & $27(149)$ & J14 & M012001 & L13 & V3 \\
\hline $31(003)$ & $109(001)$ & 30 (019) & $\mathrm{J} 17$ & M012004 & L16 & \\
\hline $32(140)$ & $110(044)$ & $44(087)$ & $\mathrm{K} 1$ & M012008 & $\mathrm{N} 13$ & \\
\hline $33(008)$ & $113(004)$ & $66(115)$ & $\mathrm{K} 2$ & M012009 & O7 & \\
\hline $36(009)$ & 115 (107) & $68(053)$ & K6 & M012010 & $\mathrm{P} 10$ & \\
\hline 37 (043) & $118(138)$ & $73(084)^{\prime \prime}$ & K9 & M012016 & $\mathrm{P} 15$ & \\
\hline $38(046)$ & $\begin{array}{l}128 \\
(047)^{* * * *}\end{array}$ & $75(014)^{\prime \prime \prime}$ & $\mathrm{L} 17$ & M012021 & Q1 & \\
\hline $41(042)$ & $129(144)$ & $80(055)$ & L8 & M012024 & Q2 & \\
\hline $56(142)^{*}$ & $131(112)$ & 87 (018) & L9 & M012027 & Q7 & \\
\hline $57(074)$ & $132(141)^{* * *}$ & $97(172)$ & M4 & M012028 & $\mathrm{R} 11$ & \\
\hline $58(077)$ & $138(073)$ & $99(015)$ & M8 & M012031^ & R9 & \\
\hline $61(108)$ & $143(081)$ & $104(085)$ & $\mathrm{N} 11$ & M012033 & S1 & \\
\hline $64(048)^{\star *}$ & $148(078)^{\star * *}$ & 105 (113) & $\mathrm{N} 14$ & M012036 & $\mathrm{T} 1$ & \\
\hline $70(011)$ & $151(105)$ & $122(052)$ & N16 & M012041 & M012002 & \\
\hline $72(106)$ & $155(146)$ & $123(117)$ & $\mathrm{N} 17$ & M012044 & M012012 & \\
\hline $82(006)$ & $157(002)$ & $126(116)$ & N19 & M012045 & M012017 & \\
\hline & $158(041)$ & $134(148)$ & $\mathrm{O} 2$ & & M012020 & \\
\hline & $159(110)$ & $136(152)$ & $\mathrm{O} 4$ & & M012022 & \\
\hline & $173(111)$ & $145(088)$ & O9 & & M012025 & \\
\hline & $178(007)$ & $150(082)$ & $\mathrm{P} 12$ & & M012029 & \\
\hline & & $162(120)$ & $\mathrm{P} 13$ & & M012035 & \\
\hline & & $165(054)$ & $\mathrm{P} 14$ & & M012040 & \\
\hline & & $171(118)$ & P16 & & M012042 & \\
\hline & & $172(016)$ & Q6 & & M012046 & \\
\hline & & $176(049)^{\prime}$ & Q8 & & M012048 & \\
\hline & & & Q9 & & & \\
\hline & & & $\mathrm{R} 12$ & & & \\
\hline
\end{tabular}


As to why some items are categorised differently, see the notes below.

* This item should be categorised as algebra according to the 1980 curriculum since it involved letters and variables. IEA considered it an item about proportions and thus arithmetic.

** This item is an equation $10^{2} \cdot 10^{3}=10^{n}$ and should be considered algebra according to the 1980 curriculum. IEA considered it arithmetic since it involves power rules.

${ }^{* * *}$ Item involves distance, velocity, time, and requires knowledge of corresponding formula. Following the 1980 curriculum, it should be categorised as algebra.

${ }_{* * * *}$ The item involves proportionality. Three numbers are given and the fourth unknown is given the symbol $n$. According to the 1980 curriculum, it should be categorised as algebra.

'Item involves computations with negative numbers. Items that involve computation with negative numbers are categorised as algebra in SIMS. This is probably related to the fact that whole numbers belonged to arithmetic while integers belonged to algebra according to IEA. If the 1980 curriculum is followed, the item is arithmetic.

"' The item involves powers and according to IEA powers belongs to algebra. If the 1980 curriculum is followed, the item is arithmetic.

" The item concerns the order of numbers and involves positive and negative rational numbers. As noted earlier, negative numbers belonged to algebra according to IEA, so did rationals. Thus, the item was categorised as algebra by SIMS. If the 1980 curriculum is followed, the item is arithmetic.

$\wedge$ Item involves velocity, time, and distance and requires knowledge of the formula $d=$ $v \cdot t$. It should be categorised as algebra according to the 1980 curriculum.

The numbering of the items is not uniform or consistent. The reason for this is explained below.

Each SIMS1980 item has two numbers. First and outside the parenthesis is the numbering in the report by Pelgrum et al., which contains complete and reader friendly versions of the items. ${ }^{100}$ Within parenthesis is the number in the item bank, see for instance a technical report by Travers and Westbury. ${ }^{101}$ In this technical report you also find the scheme for the categorisation of the items. The items in Table 3 are the ones used in the computations of the national results accounted for in the report by Pelgrum et al. ${ }^{102}$

As to the numbering of the TIMSS1995 items, the shorter type stems from the original TIMSS1995 test and these items were released in a 1997 TIMSS-report with the original numbering. ${ }^{103}$ The not released items were reused in TIMSS1999 and TIMSS2003. In those tests, a new numbering system had been introduced. Thus, when the rest of the original TIMSS1995 was released, they got the new type of numbers. ${ }^{104}$ The numbers of the original TIMSS1995 items then begin with M01.

100 Pelgrum et al. (1986), 18-96.

101 Kenneth J. Travers and Ian Westbury, The IEA study of mathematics. 1, Analysis of mathematics curricula. Supplement. (New York: International Association for the Evaluation of Educational Achievement, 1989).

102 Pelgrum et al. (1986).

103 Third International Mathematics and Science Study, TIMSS Mathematics Items : Released Set for Population 2 (seventh and Eighth Grades ): IEA's Third International Mathematics and Science Study. (IEA TIMSS, 1997)

104 See on-line TIMSS publications in the list of references. 
Johan Prytz

Appendix B. Statistics on national exams (Standardprov) in year 9, 1980-1995

Table 4. Different types of items in the exams, 1980-1995

\begin{tabular}{|c|c|c|c|c|c|c|c|c|c|}
\hline School year & \# Items & $\begin{array}{l}\text { Arithme } \\
\text { \# pure }\end{array}$ & $\%$ pure & \# appl & $\%$ appl & $\begin{array}{l}\text { Percent } \\
\text { \# pure }\end{array}$ & $\%$ pure & \# appl & $\begin{array}{c}\% \\
\text { appl }\end{array}$ \\
\hline $1980 / 81$ & 124 & 83 & $80 \%$ & 15 & $14 \%$ & 0 & $0 \%$ & 0 & $0 \%$ \\
\hline $1981 / 82$ & 124 & 69 & $56 \%$ & 14 & $11 \%$ & 15 & $12 \%$ & 8 & $6 \%$ \\
\hline $1982 / 83$ & 95 & 41 & $43 \%$ & 26 & $27 \%$ & 3 & $3 \%$ & 10 & $11 \%$ \\
\hline $1983 / 84$ & 95 & 39 & $41 \%$ & 29 & $31 \%$ & 3 & $3 \%$ & 10 & $11 \%$ \\
\hline $1984 / 85$ & 48 & 17 & $35 \%$ & 10 & $21 \%$ & 1 & $2 \%$ & 9 & $19 \%$ \\
\hline $1985 / 86$ & - & & & & & & & & \\
\hline $1986 / 87$ & 60 & 12 & $20 \%$ & 13 & $22 \%$ & 0 & $0 \%$ & 10 & $17 \%$ \\
\hline $1987 / 88$ & 60 & 13 & $22 \%$ & 12 & $20 \%$ & 0 & $0 \%$ & 11 & $18 \%$ \\
\hline $1988 / 89$ & 60 & 8 & $13 \%$ & 11 & $18 \%$ & 0 & $0 \%$ & 11 & $18 \%$ \\
\hline $1989 / 90$ & 31 & 3 & $10 \%$ & 3 & $10 \%$ & 0 & $0 \%$ & 6 & $19 \%$ \\
\hline $1990 / 91$ & 28 & 5 & $18 \%$ & 5 & $18 \%$ & 0 & $0 \%$ & 4 & $14 \%$ \\
\hline $1991 / 92$ & 44 & 10 & $23 \%$ & 6 & $14 \%$ & 0 & $0 \%$ & 6 & $14 \%$ \\
\hline $1992 / 93$ & 33 & 7 & $21 \%$ & 6 & $18 \%$ & 0 & $0 \%$ & 2 & $6 \%$ \\
\hline $1993 / 94$ & 32 & 6 & $19 \%$ & 4 & $13 \%$ & 0 & $0 \%$ & 3 & $9 \%$ \\
\hline $1994 / 95$ & 39 & 8 & $21 \%$ & 8 & $21 \%$ & 1 & $3 \%$ & 1 & $3 \%$ \\
\hline
\end{tabular}

\begin{tabular}{|c|c|c|c|c|c|c|c|c|c|}
\hline School year & \# Items & $\begin{array}{l}\text { Proport } \\
\text { \# pure }\end{array}$ & $\%$ pure & \# appl & $\%$ appl & $\begin{array}{l}\text { Algebra } \\
\text { \# pure }\end{array}$ & $\%$ pure & \# appl & $\begin{array}{c}\% \\
\text { appl }\end{array}$ \\
\hline $1980 / 81$ & 124 & 0 & $0 \%$ & 0 & $0 \%$ & 4 & $4 \%$ & 2 & $2 \%$ \\
\hline $1981 / 82$ & 124 & 0 & $0 \%$ & 3 & $2 \%$ & 5 & $4 \%$ & 10 & $8 \%$ \\
\hline $1982 / 83$ & 95 & 0 & $0 \%$ & 4 & $4 \%$ & 4 & $4 \%$ & 7 & $7 \%$ \\
\hline $1983 / 84$ & 95 & 0 & $0 \%$ & 5 & $5 \%$ & 6 & $6 \%$ & 3 & $3 \%$ \\
\hline $1984 / 85$ & 48 & 0 & $0 \%$ & 3 & $6 \%$ & 4 & $8 \%$ & 4 & $8 \%$ \\
\hline $1985 / 86$ & - & & & & & & & & \\
\hline $1986 / 87$ & 60 & 0 & $0 \%$ & 7 & $12 \%$ & 9 & $15 \%$ & 9 & $15 \%$ \\
\hline $1987 / 88$ & 60 & 0 & $0 \%$ & 6 & $10 \%$ & 10 & $17 \%$ & 8 & $13 \%$ \\
\hline $1988 / 89$ & 60 & 0 & $0 \%$ & 9 & $15 \%$ & 7 & $12 \%$ & 14 & $23 \%$ \\
\hline $1989 / 90$ & 31 & 0 & $0 \%$ & 2 & $6 \%$ & 5 & $16 \%$ & 12 & $39 \%$ \\
\hline $1990 / 91$ & 28 & 0 & $0 \%$ & 2 & $7 \%$ & 4 & $14 \%$ & 8 & $29 \%$ \\
\hline $1991 / 92$ & 44 & 0 & $0 \%$ & 3 & $7 \%$ & 10 & $23 \%$ & 9 & $20 \%$ \\
\hline $1992 / 93$ & 33 & 0 & $0 \%$ & 3 & $9 \%$ & 8 & $24 \%$ & 7 & $21 \%$ \\
\hline $1993 / 94$ & 32 & 1 & $3 \%$ & 1 & $3 \%$ & 6 & $19 \%$ & 11 & $34 \%$ \\
\hline $1994 / 95$ & 39 & 1 & $3 \%$ & 0 & $0 \%$ & 7 & $18 \%$ & 13 & $33 \%$ \\
\hline
\end{tabular}


Table 4 should be understood as follows. ${ }^{105} \mathrm{~A}$ basic property of the categories in the table is that "Percentage," "Proportionality," and "Algebra" are subcategories of "Arithmetic." This is based on the fact that almost all items, only with few exceptions, involved calculations with numbers, known or unknown, either with addition, subtraction, multiplication, or division. The numbers in Table A under the heading "Arithmetic" concerns items that could not be classified as "Percentage," "Proportionality," or "Algebra." If the four categories are related to the topics in 1980 syllabus, the categories "Arithmetic," "Percentage," and "Proportionality" belong to the syllabus topic Arithmetic and the category "Algebra" belongs to the syllabus topic Algebra. If an item involves non-mathematical objects, it is classified as applied (appl). If an item just involves mathematical objects, it is classified as pure.

Items that involved statistics or geometry, which were syllabus topics, have been categorised as "Arithmetic," "Percentage," "Proportionality," or "Algebra." This is indeed an ad hoc arrangement and the reason for it is that the article primarily concerns arithmetic and algebra. These are just the most basic principles underlying the categorisation and the analysis of the items (see Appendix C for a more comprehensive account).

Each test comprised two or three subtests. The explicit themes of the subtests were either arithmetic or problem solving.

Table 5. Distribution of number of algebra items on subtests, 1980-1995

\begin{tabular}{|c|c|c|c|c|c|c|c|c|c|c|c|c|c|c|}
\hline $\begin{array}{l}\text { Sub- } \\
\text { test }\end{array}$ & & $\begin{array}{c}1981 / \\
82\end{array}$ & $\begin{array}{c}1982 / \\
83\end{array}$ & $\begin{array}{c}1983 / \\
84\end{array}$ & $\begin{array}{c}1984 / \\
85\end{array}$ & $\begin{array}{c}1986 / \\
87\end{array}$ & $\begin{array}{c}1987 / \\
88\end{array}$ & $\begin{array}{c}1988 / \\
98\end{array}$ & $\begin{array}{c}1989 / \\
90\end{array}$ & $\begin{array}{c}1990 / \\
91\end{array}$ & $\begin{array}{c}1991 / \\
92\end{array}$ & $\begin{array}{c}1992 / \\
93\end{array}$ & $\begin{array}{c}1993 / \\
94\end{array}$ & $\begin{array}{c}1994 / \\
95\end{array}$ \\
\hline 1 & \# & 0 & 2 & 1 & 0 & 5 & 5 & 8 & 11 & 5 & 13 & 10 & 8 & 13 \\
\hline 1 & $\%$ & $0 \%$ & $3 \%$ & $2 \%$ & $0 \%$ & $18 \%$ & $18 \%$ & $29 \%$ & $65 \%$ & $31 \%$ & $30 \%$ & $30 \%$ & $25 \%$ & $33 \%$ \\
\hline 2 & \# & 11 & 8 & 8 & 4 & 7 & 7 & 7 & 6 & 7 & 6 & 5 & 9 & 7 \\
\hline 2 & $\%$ & $46 \%$ & $40 \%$ & $44 \%$ & $40 \%$ & $44 \%$ & $44 \%$ & $44 \%$ & $43 \%$ & $58 \%$ & $14 \%$ & $15 \%$ & $28 \%$ & $18 \%$ \\
\hline 3 & \# & 4 & 1 & 0 & 4 & 6 & 6 & 6 & & & & & & \\
\hline 3 & $\%$ & $20 \%$ & $7 \%$ & $0 \%$ & $27 \%$ & $38 \%$ & $38 \%$ & $38 \%$ & & & & & & \\
\hline
\end{tabular}

Light grey indicates arithmetic as explicit theme.

Dark grey indicates problem solving as explicit theme.

The percentage shares concerns shares of algebra items of the total number of items in each subtest.

The "Arithmetic," "Percentage," and "Proportionality" items constitute the rest of the items in each subtest. Together they constitute the syllabus topic Arithmetic.

105 In $1984 / 85$ the test was given in year 8 . No test was given in 1985/86. 


\section{Appendix C. The analysis of the national exams (standardprov)}

1) Almost all items involved arithmetic in the sense that they involved numbers (known or unknown) and the solutions required at least one calculation with one of the four arithmetical operations. The exceptions are very few and concern the handling of coordinate systems (fewer than one item per test).

2 ) All items have been categorised as either pure or applied. Pure means that an item involves only mathematical objects, that is, numbers or geometrical quantities (lines, surfaces, and bodies). Applied means that the item involves any type of non-mathematical objects. A typical item of the arithmetic pure category concerns the execution of a calculation $a^{\star} b=$ where $a$ and $b$ are numbers and ${ }^{\star}$ is an arithmetical operation. Strictly speaking, this is an equation since there is an equality and the right side is unknown. However, in the light of the formulations about algebra in grade 7-9 in the curriculum, I have not considered these items as algebra. Note that there were no items of the type $a^{*}=b$, where the distinction between algebra and arithmetic is less straight forward.

3 ) The category "Arithmetic" in Table 4 (Appendix B) contains the items that are left when the items belonging to "Percentage," "Proportions," and "Algebra" have been singled out. Thus, the latter three categories are subcategories to the "Arithmetic" category. The categories "Arithmetic," "Percentage," and "Proportions" covers the content of the following topics in the 1980 curriculum

- Basic arithmetic (Grundläggande aritmetik)

- Real numbers (Reella tal)

- Percentage (Procent)

- Measurements and units (Mätningar och enheter)

4 ) To single out the algebra items, I have used the underlined parts in the description of algebra for years $7-9$ in the 1980 curriculum: ${ }^{106}$

Solution of simple equations $[a \cdot x+/-b=c$, where $a, b$ and $c$ are numbers] mainly by testing and starting from problems. The function concept is introduced by practical experiments. Interpretation of simple functions, depicted in the first quadrant of a coordinate system. Calculation of function values by inserting them into formulas linked to everyday life or to others school subjects.

Interpretation and construction of graphs throughout the coordinate system. Writing, simplifying and calculating expressions. Parenthesis expressions, breakdown of factors as well as the squared rules and conjugate rule are treated, but with particular consideration for the students' maturity, interest, and needs. Equations of the first degree, even with unknown in both parts, as well with parenthesis and fractional numbers. Problem solving with simple equations. Linear functions $[y=k \cdot x+m]_{2}$ especially those indicating proportionality $[y=k \cdot x]$. Linear equation systems and simple second degree equations, mainly in problem solving and preferably with graphical solution. 
Items that require that the students know and can handle formulas have been categorised as "Algebra." This means that several items involving geometry have been classified as algebra since the solution requires knowledge of handling of formulas regarding areas, volumes, and relations between angles. For the same reason, items that concern the relation between distance, velocity, and time and the formula $d=v \cdot t$ have been categorised as "Algebra." To separate items about linear functions indicating proportionality from other items about proportionality, the critical element has been the change factor $k$. To be categorised as the former, there needs to be an explicit formulation concerning rate of change.

5 ) To nuance the arithmetic topic and to make the analysis more compatible with today's educational research on algebra, items regarding percentage and proportionality have been singled out. These items do not meet the characterisation of algebra in the 1980 curriculum and belong to arithmetic according to the same curriculum, but they often require a kind of thinking about numbers and quantities that goes beyond doing just calculations. Researchers in mathematics education today often see this as a kind of algebraic thinking. When calculating with percentage, especially when solving applied problems, students should relate this to the basic equality percentage share $=$ part/whole and sort out what is the part and what is the whole. When students are solving problems about proportionality, where I include scale, they should relate this to the notion $a$ is to $b$ as $c$ is to $d$, which translates into arithmetic as $a / b=c / d$. In all items in this category, one of the terms in the equalities is unknown, which in great many cases makes the solution a bit more complex than executing the operation $a^{*} b=$, where $a$ and $b$ are numbers and ${ }^{*}$ is an arithmetical operation.

$6)$ The "Algebra" categoryhaspriorityoverthe "Percentage" and "Proportionality" categories. This means that items that belong to "Algebra" and one of the other twohasbeen categorised as "Algebra." However, these items areveryfew. There are no overlaps between the "Percentage" and "Proportionality" categories. 
Johan Prytz

\section{Appendix D. Topics in textbooks, year 7-9}

Table 6. The distribution of pages and chapters dedicated to different topics in the textbooks intended for years 7-9.

\begin{tabular}{|c|c|c|c|c|c|c|c|c|c|}
\hline Authors & Year & Copyright & $E d$ & \# pages & Arith. & Alg. & Geom. & Stat. & Sum \\
\hline Alvin & 7 & 1979 & & 261 & $60 \%$ & $17 \%$ & $17 \%$ & $0 \%$ & $94 \%$ \\
\hline Alvin & 8 & 1980 & & 278 & $27 \%$ & $29 \%$ & $9 \%$ & $17 \%$ & $82 \%$ \\
\hline \multirow[t]{3}{*}{ Alvin } & 9 & 1981 & & 271 & $11 \%$ & $30 \%$ & $29 \%$ & $0 \%$ & $69 \%$ \\
\hline & \multicolumn{4}{|c|}{ Average share } & $33 \%$ & $25 \%$ & $18 \%$ & $6 \%$ & \\
\hline & \multicolumn{4}{|c|}{ Number of pages year 7-9 } & 262 & 204 & 146 & 48 & \\
\hline Undvall & 7 & 1979 & 2 & 153 & $58 \%$ & $20 \%$ & $16 \%$ & $0 \%$ & $94 \%$ \\
\hline Undvall & 8 & 1980 & 2 & 157 & $24 \%$ & $34 \%$ & $16 \%$ & $12 \%$ & $86 \%$ \\
\hline \multirow[t]{3}{*}{ Undvall } & 9 & 1981 & 2 & 173 & $24 \%$ & $34 \%$ & $12 \%$ & $13 \%$ & $83 \%$ \\
\hline & \multicolumn{4}{|c|}{ Average share } & $35 \%$ & $29 \%$ & $15 \%$ & $8 \%$ & \\
\hline & \multicolumn{4}{|c|}{ Number of pages year 7-9 } & 168 & 143 & 70 & 42 & \\
\hline Undvall & 7 & 1985 & & 209 & $57 \%$ & $9 \%$ & $16 \%$ & $0 \%$ & $82 \%$ \\
\hline Undvall & 8 & 1986 & & 217 & $22 \%$ & $29 \%$ & $16 \%$ & $14 \%$ & $80 \%$ \\
\hline \multirow[t]{3}{*}{ Undvall } & 9 & 1987 & & 242 & $21 \%$ & $40 \%$ & $9 \%$ & $6 \%$ & $76 \%$ \\
\hline & \multicolumn{4}{|c|}{ Average share } & $33 \%$ & $26 \%$ & $13 \%$ & $7 \%$ & \\
\hline & \multicolumn{4}{|c|}{ Number of pages year 7-9 } & 218 & 178 & 88 & 45 & \\
\hline Undvall & 7 & 1993 & 1 & 272 & $42 \%$ & $13 \%$ & $14 \%$ & $9 \%$ & $78 \%$ \\
\hline Undvall & 8 & 1991 & 1 & 276 & $34 \%$ & $20 \%$ & $15 \%$ & $10 \%$ & $78 \%$ \\
\hline \multirow[t]{3}{*}{ Undvall } & 9 & 1992 & 1 & 278 & $26 \%$ & $40 \%$ & $10 \%$ & $0 \%$ & $76 \%$ \\
\hline & \multicolumn{4}{|c|}{ Average share } & $34 \%$ & $24 \%$ & $13 \%$ & $6 \%$ & \\
\hline & \multicolumn{4}{|c|}{ Number of pages year 7-9 } & 280 & 200 & 108 & 52 & \\
\hline Mårtensson et al. & 7 & 1982 & 1 & 320 & $50 \%$ & $19 \%$ & $31 \%$ & $0 \%$ & $100 \%$ \\
\hline Mårtensson et al. & 8 & 1983 & 1 & 314 & $19 \%$ & $31 \%$ & $31 \%$ & $15 \%$ & $96 \%$ \\
\hline \multirow[t]{3}{*}{ Mårtensson et al. } & 9 & 1984 & 1 & 196 & $24 \%$ & $33 \%$ & $32 \%$ & $11 \%$ & $99 \%$ \\
\hline & \multicolumn{4}{|c|}{ Average share } & $31 \%$ & $28 \%$ & $31 \%$ & $9 \%$ & $0 \%$ \\
\hline & \multicolumn{4}{|c|}{ Number of pages year 7-9 } & 266 & 224 & 258 & 69 & $0,0 \%$ \\
\hline Mårtensson et al. & 7 & 1988 & 3 & 309 & $48 \%$ & $9 \%$ & $27 \%$ & $0 \%$ & $84 \%$ \\
\hline Mårtensson et al. & 8 & 1989 & 3 & 296 & $33 \%$ & $18 \%$ & $29 \%$ & $12 \%$ & $92 \%$ \\
\hline \multirow[t]{3}{*}{ Mårtensson et al. } & 9 & 1989 & 3 & 321 & $20 \%$ & $38 \%$ & $23 \%$ & $7 \%$ & $88 \%$ \\
\hline & \multicolumn{4}{|c|}{ Average share } & $34 \%$ & $22 \%$ & $27 \%$ & $6 \%$ & \\
\hline & \multicolumn{4}{|c|}{ Number of pages year 7-9 } & 309 & 206 & 245 & 57 & \\
\hline Skoogh et al. & 7 & 1989 & 1 & 360 & $88 \%$ & $0 \%$ & $13 \%$ & $0 \%$ & $100 \%$ \\
\hline Skoogh et al. & 8 & 1990 & 1 & 360 & $27 \%$ & $27 \%$ & $22 \%$ & $24 \%$ & $99 \%$ \\
\hline \multirow[t]{3}{*}{ Skoogh et al. } & 9 & 1991 & 1 & 360 & $26 \%$ & $32 \%$ & $17 \%$ & $0 \%$ & $75 \%$ \\
\hline & \multicolumn{4}{|c|}{ Average share } & $47 \%$ & $20 \%$ & $17 \%$ & $8 \%$ & \\
\hline & \multicolumn{4}{|c|}{ Number of pages year 7-9 } & 504 & 212 & 184 & 86 & \\
\hline
\end{tabular}

